Article

\title{
Experimental Investigations on the Performances of Composite Building Materials Based on Industrial Crops and Volcanic Rocks
}

\author{
Raluca Iștoan *, Daniela Roxana Tămaș-Gavrea and Daniela Lucia Manea \\ Department of Civil Engineering and Management, Faculty of Construction, \\ Technical University of Cluj-Napoca, 28 Memorandumului Street, 400114 Cluj-Napoca, Romania; \\ roxana.tibrea@ccm.utcluj.ro (D.R.T.-G.); daniela.manea@ccm.utcluj.ro (D.L.M.) \\ * Correspondence: ralucafernea@ccm.utcluj.ro
}

Received: 16 January 2020; Accepted: 8 February 2020; Published: 11 February 2020

\begin{abstract}
Interdisciplinary and sustainability represent the main characteristics of this paper due to the fact that this research is offering a connection between two main areas-agronomy and construction, by using hemp shiv for the design of new building materials, which can increase the sustainability level of the building industry. For this reason, the main scope of this study is based on the investigation of a new category of composite building materials-lightweight mortars based on hemp shiv, volcanic rocks and white cement-which contribute to a positive environmental impact and help to increase indoor comfort. A complex report was carried out on two segments. The first one is focused upon the characteristics of the raw materials from the composition of the new materials, while the second segment presents a detailed analysis of these composites including morphological and chemical investigation, pyrolytic and fire behavior, compression and flexural strengths, and acoustic and thermal characteristics. The proposed recipes have as a variable volcanic rocks, while the hemp and the binder maintain their volumes and properties. The results were analyzed according to the influence of volcanic rocks on the new composites.
\end{abstract}

Keywords: sustainability; hemp; sound absorption; thermal conductivity; fire characteristics; mechanical properties; microscopy; thermal analysis; X-ray diffraction

\section{Introduction}

Sustainability and building materials are two different parts that together can contribute to a new perspective on the building industry. Constructions today play an important and critical role in developing a sustainable society [1]. For this reason, sustainable development represents a new challenge for each sector to become environmentally-friendly, by protecting the planet's limited resources and preventing additional pollution. During the last years of activity, the construction sector has supported the tendency to build in a more responsible way, so far as environmental and human life protection are concerned. New keywords define buildings such as passive, green, eco-friendly, sustainable and so forth. Different natural and traditional resources such as straw bale [2], hemp [3], flax [4], cob [5], sheep wool [6] and so forth are reconsidered as building materials. Moreover, new composite materials based on waste, such as glass [7,8], rubber [9] and so forth, have been studied and investigated. The use of the hemp shiv as a raw building material is not new; it was rediscovered after 1990 [10]. Its main characteristics concern improving sound and thermal performance, and having a positive impact on the environment, air-permeability, preventing condense formation and waterproofing [11]. New approaches with hemp shiv—which is regarded as a waste product obtained after the extraction of the fibers for the textile industry-have been taken into 
consideration in the construction sector. There is a significant number of studies on hemp shiv with lime, which is a composite material named hempcrete [12-14], but there are only few studies that concern hemp shiv with cement [15-19].

Due to the fact that hemp shiv presents poor fire resistance, a new approach can be made with volcanic rocks, which are natural products with higher fire resistance [20]. These materials are usually found in the composition of mortars used in the rehabilitation process of the walls, because of their increased mechanical resistances [21]. They also present sound and thermal properties, as well as a low density, which will help the workability of the mortar. Durable and with higher strength properties for structural application [20], volcanic rocks are low cost materials [22] that also present fire retarding properties for steel structures [23].

Therefore, the purpose of this paper is to analyze the impact of the volcanic rocks when these are incorporated in hemp-cement composite materials used as interior mortars. These building materials are developed to be suitable not only for eco-friendly construction but also in regular buildings made from concrete, steel, and so forth, where they can increase indoor comfort.

\section{Materials and Methods}

\subsection{Raw Materials}

The composition of the new materials is designed to increase indoor comfort by developing new types of lightweight mortars, obtained as prefabricated plates. In order to understand the characteristics of the new composites, hemp shiv, natural and treated; volcanic rocks, perlite and vermiculite; and binders, white cement and hydrated lime, were analyzed.

\subsubsection{Hemp Shiv}

The hemp shiv used for the new composites was received from HempFlax Romania (Pianu De Jos, Alba, Romania). The chemical structure of the hemp shiv is represented by cellulose $44 \%$, hemicellulose $18 \%-27 \%$, lignin $22 \%-28 \%$, extractives (fatty acids, waxes, sterols, triglycerides, steryl esters, glycosides, fatty alcohols, terpenes, phenolics, simple sugars, alkaloids, pectins, gums and essential oils) $1 \%-6 \%$ and ash $1 \%-2 \%$ according to Reference [24]. The percentages may differ depending on the hemp variety used. Hemp shiv presents a natural structure, shown in Figure 1a, similar to wood fibers, with dimensions from 1 to $8 \mathrm{~mm}$, as follows: $4-8 \mathrm{~mm}(48.75 \%), 2-4 \mathrm{~mm}(22.5 \%), 1-2 \mathrm{~mm}(25 \%)$ and $0.25-1 \mathrm{~mm}(4.75 \%)$. The sorting procedure was made using the Controls sort system with 6 sieves of $0.25 ; 0.5 ; 1 ; 2 ; 4$ and $8 \mathrm{~mm}$. The relative humidity of the hemp shiv was approximately $7 \%$ and the density was $100 \mathrm{~kg} / \mathrm{m}^{3}$. The density was found to be similar to that found in the investigation of Reference [13]. The microscopic image of the hemp shiv presented in Figure 1b shows the cellular porous microstructure with two different sizes of longitudinal channels. According to References [25,26], the small ones range from $20-50 \mu \mathrm{m}$ and are called xylem rays, whereas the bigger ones are on average around $50-100 \mu \mathrm{m}$ and are named vessels. The surface walls of the vessel show perforations that permit a connection with the xylem ray, making it possible for the moisture to pass from one cell to the other. Regularly, the vessels are individually arranged and the pore frequency is about 20.8 vessels $/ \mathrm{mm}^{2}$ [26]. The thermal analyses of the natural hemp shiv, presented in Figure 1c, showed a total degradation of $81.20 \%$. The hemp shiv lost $3.6 \%$ on the first temperature interval from $20-200{ }^{\circ} \mathrm{C}$ and $77.6 \%$ on the second one, from 200 and $1000{ }^{\circ} \mathrm{C}$. Compared with References $[27,28]$, the second temperature interval is defined by the thermal combustion of hemicellulose and cellulose. The X-ray diffraction (XRD) of the hemp shiv was presented in a previous study [19], where the higher peak was recorded at $2 \theta=22.66^{\circ}$, similar to the studies of References [25,29]. The peak represents the crystallographic plane of the cellulose. Because of the similarity with the other two studies mentioned before, the hemp shiv presents crystalline and amorphous phases. The cellulose represents the crystalline part of the hemp shiv. The hemicellulose and lignin make the amorphous part, due to the hydroxyl group [25,29]. 


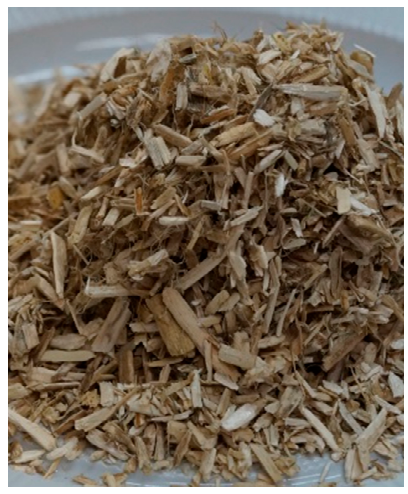

(a)

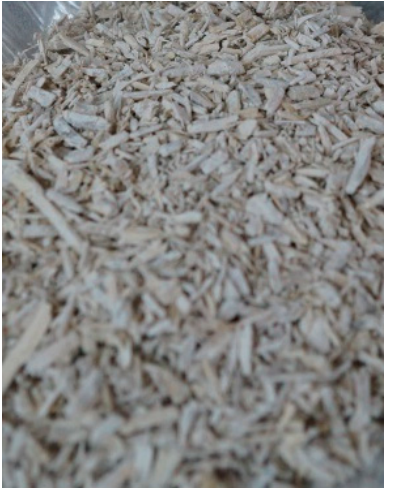

(d)

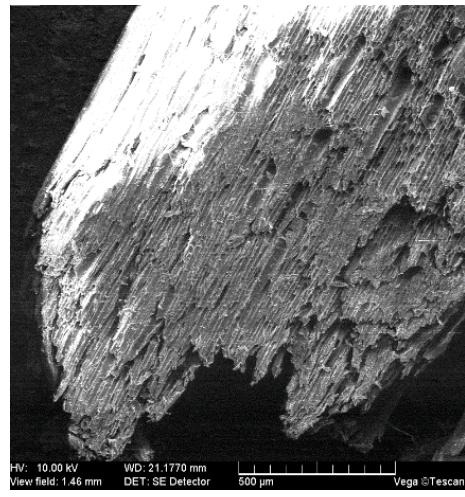

(b)

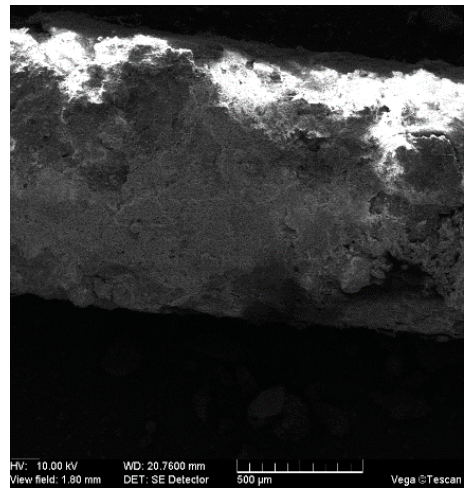

(e)

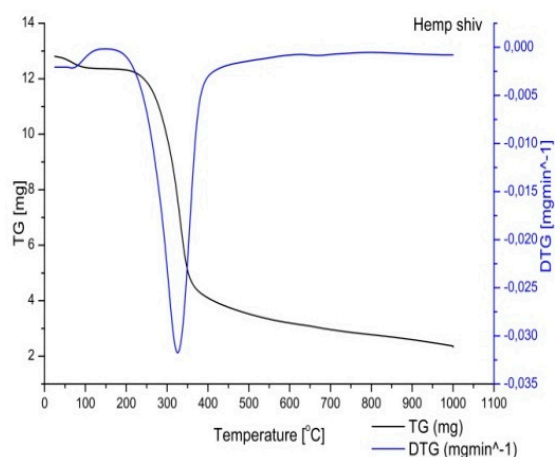

(c)

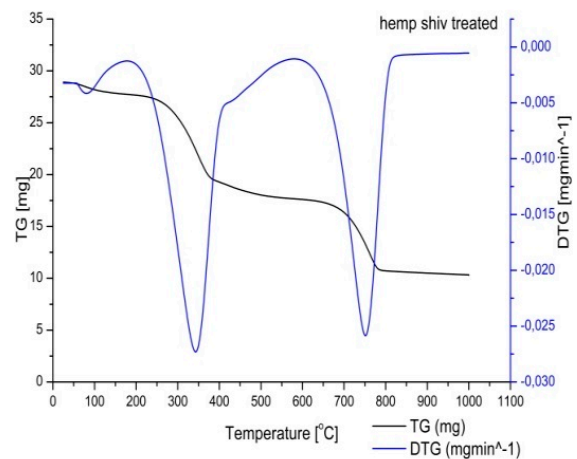

(f)

Figure 1. Industrial crop (a) natural hemp shiv; (b) natural hemp microscopy; (c) natural hemp thermal analysis; (d) treated hemp shiv; (e) treated hemp microscopy; (f) treated hemp thermal analysis.

The hemp shiv used in the recipes was treated with a lime solution, intended to improve the antiseptic and the fire characteristics of biomass. The treatment procedure consisted of soaking the hemp shiv under agitation for $5 \mathrm{~min}$ in a lime milk solution, until all the hemp shiv was covered by the solution. Successively, the hemp was dried under normal laboratory conditions at $24^{\circ} \mathrm{C}$ and a humidity of $40 \%$. Applying the lime solution to the hemp did not modify the density of the fibers, as highlighted in Reference [30]. The density kept the same value of $100 \mathrm{~kg} / \mathrm{m}^{3}$. Instead, the relative humidity changed, by decreasing to $4 \%$. Figure $1 \mathrm{~d}$ shows the visual aspect of the hemp shiv covered with lime solution, meanwhile Figure 1e captures the microscopic surface of hemp shiv at a scale of $500 \mu \mathrm{m}$. The image presents similarities with the studies in References [31,32]. The thermal analyses of the treated hemp shown in Figure If showed an improvement of the pyrolytic behavior of this plant, the degradation percentage being $64.15 \%$. By treating the hemp shiv with lime solution, the mass loss was smaller by $17 \%$ at higher temperatures, in comparison with the natural ones. The diagram of the treated hemp shiv showed three temperature intervals. The first one, from 20 to $200{ }^{\circ} \mathrm{C}$, presented $4.24 \%$ degradation of the shiv which is attributed to the water released [33]. The deterioration from the second and the third temperature interval, from 200 to $580{ }^{\circ} \mathrm{C}(34.74 \%)$ and 580 to $100{ }^{\circ} \mathrm{C}(25.37 \%)$ is characteristic of the lime degradation process [12]. The X-ray diffraction diagram of the treated hemp shiv indicated the same shape of graph as with the natural hemp shiv from Reference [19]. The difference consisted in the identification of new crystalline compounds- $\mathrm{Ca}(\mathrm{OH})_{2}$ calcium hydroxide and $\mathrm{CaCO}_{3}$ calcium carbonate. The central peak remains in the same position but varies in intensity and secondary peaks appear where the main compound is made of the carbonyl group. A remark regarding these changes is made in Reference [30], which assumes that by applying the lime treatment a part of the amorphous components of hemp, such as hemicelluloses, pectins and waxes, are removed. 


\subsubsection{Volcanic Rocks}

The volcanic rocks were procured by Procema Perlit (Jilava, Ilfov, Romania). The rocks were selected based on composition, to reinforce the fire behavior of the composite materials, but also to grow the porosity of the elements. They are natural products, with significant thermal properties due to the porous structure. The volcanic rocks, perlite and vermiculite were chosen for the new compositions. The two igneous rocks were obtained after the cooling of volcanic eruptions. The main constituents of the perlite rock are $\mathrm{SiO}_{2}, \mathrm{Al}_{2} \mathrm{O}_{3}, \mathrm{~K}_{2} \mathrm{O}, \mathrm{Na}_{2} \mathrm{O}$; when hydrated it can also contain $\mathrm{TiO}_{2}, \mathrm{CaO}, \mathrm{MgO}$, and $\mathrm{Fe}_{2} \mathrm{O}_{3}$ in small quantities [34]. When it comes to vermiculite, the main components are $\mathrm{SiO}_{2}$, $\mathrm{Al}_{2} \mathrm{O}_{3}, \mathrm{Fe}_{2} \mathrm{O}_{3}, \mathrm{CaO}, \mathrm{MgO}, \mathrm{K}_{2} \mathrm{O}$ but also some small quantities of $\mathrm{Li}, \mathrm{Cr}, \mathrm{Ti}$, and $\mathrm{Ni}$ [35].

Perlite has a granular aspect, as shown in Figure 2a, with white color and it is usually used in the constructions sector as a lightweight aggregate for mortars, screeds and thermal insulation concrete. According to the manufacturer's datasheet, perlite has a density around $100-140 \mathrm{~kg} / \mathrm{m}^{3}$ (SR EN 1097-3/2002), for a grain size between 0-2.5 mm (SR EN 933/2002) and a thermal conductivity of about $0.055 \mathrm{~W} / \mathrm{mK}$ (SR EN 12667/2002). The natural humidity is about 1\% (SR EN 1097-6/2002), the crushing resistance is $0.10 \mathrm{~N} / \mathrm{mm}^{2}$ (SR EN 13055/2003) and the fire reaction is class A1. The microscopic image presented in Figure $2 \mathrm{~b}$ illustrates the exterior porous surface of a perlite grain. According to Reference [36], the unexpanded perlite can increase volume by 10 to 20 times more, when heated over $700{ }^{\circ} \mathrm{C}$, becoming an expanded perlite. The water molecules from the initial stage evaporate during the heating process, cracks appear as a consequence of the steam leak, therefore the resulting cavities will define the perlite structure [34,36,37]. The X-ray diffraction graph of perlite, from Reference [19], resembles the curve shape of powder perlite studied in Reference [38], indicating an amorphous structure already identified in previous studies $[39,40]$. The crystalline phase of perlite is provided by the compound of $\mathrm{SiO}_{2}$ and the amorphous structure is given by the aluminosilicate compounds [39].

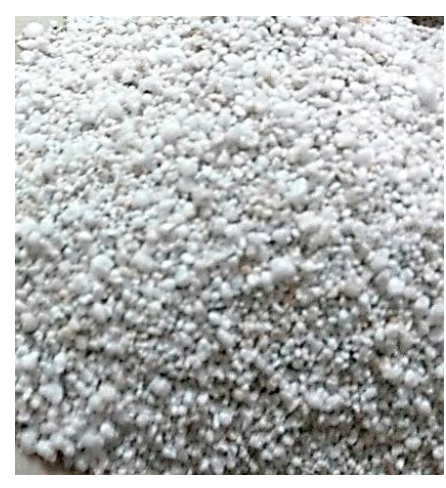

(a)

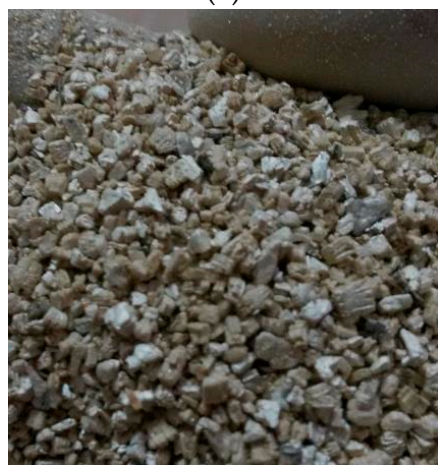

(c)

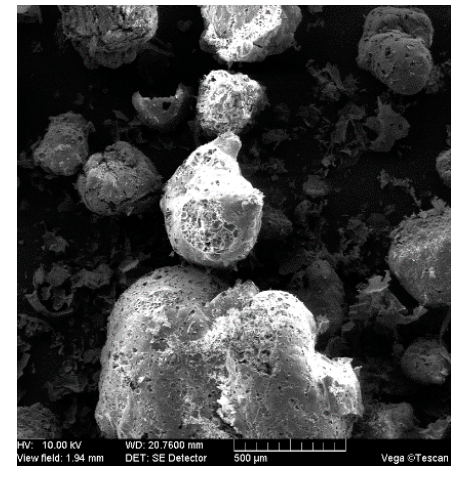

(b)

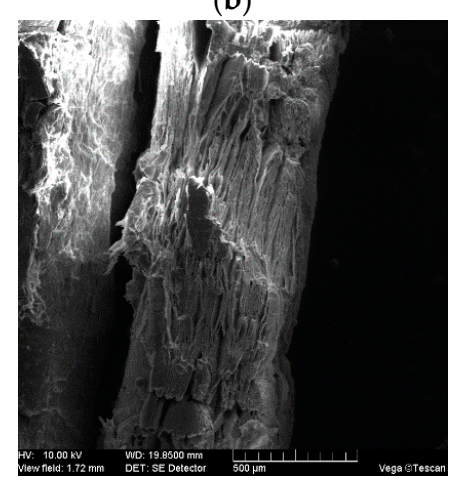

(d)

Figure 2. Volcanic rocks (a) perlite natural structure; (b) perlite microscopy; (c) vermiculite natural structure; (d) vermiculite microscopy. 
The expanded vermiculite is known as a granular product, of brown color, shown in Figure 2c, which has a mica aspect, and is rich in iron ions, magnesium and silicates. The physical characteristics of vermiculite presented in the manufacturer's datasheet, indicate a grain size from $0-0.5 \mathrm{~mm}$ (max. $5 \%$ ) and $0.5-3 \mathrm{~mm}(95 \%)$, a density of around $110-130 \mathrm{~kg} / \mathrm{m}^{3}$, whereas the absorption is around $60 \%-70 \%$ of the volume. It is usually used in horticultural substrates. Therefore, by including this product in the recipe, it was intended to analyze its behavior in composite materials. The microscopic image of the vermiculite grain captured in Figure $2 \mathrm{~d}$ showed a lamellar structure formed during the speedy heating process [20,37,41-43]. The X-ray diffraction of vermiculite [19] shows a high peak with an intensity of 800 and a diffraction angle of $2 \theta=27.4^{\circ}$. The crystallographic determination of expanded vermiculite showed that this volcanic rock presents an incomplete crystallinity, having a considerable number of amorphous compounds [20,42]; therefore, it resembles the perlite. The thermal analysis of the volcanic rocks cannot be shown due to the fact that some errors appeared in the investigation process. Some studies from the scientific literature showed that the degradation process of the perlite is defined by three temperature intervals with a maximum percentage of degradation around $2 \%[44,45]$. Reported to the vermiculite, the degradation process is around 9\% [20]. These characteristics of the volcanic rocks, that is, resistance to higher temperatures, will help decrease the degradation process of the composite hemp based materials.

\subsubsection{Binders}

The hydrated lime used for the treatment of the hemp shiv was CL80-S according to EN 459-1, produced by Carmeuse (Brasov, Romania). The chemical composition of the lime powder, according to the manufacturer's datasheet, is $\mathrm{CaO}+\mathrm{MgO}(\min .80 \%), \mathrm{CO}_{2}(\max .15 \%), \mathrm{MgO}(\max .5 \%)$ and $\mathrm{SO}_{3}$ (max. $2 \%$ ). Other laboratory tests concerned density (about $520 \mathrm{~kg} / \mathrm{m}^{3}$ ), porosity $(74 \%)$ and compactness $(26 \%)$. Lime powder is presented in Figure 3a, and the microscopy for this power at the scale of $500 \mu \mathrm{m}$ can be observed in Figure 3b. The thermal analysis is presented in Figure 3c. The maximum percentage of degradation recorded by lime powder was $35.11 \%$. The decomposition analysis was defined by two intervals of temperature. The first one, between $20-540{ }^{\circ} \mathrm{C}$, where the sample recorded a decrease of mass by $11 \%$ while on the second temperature interval of $540-1000{ }^{\circ} \mathrm{C}$ was $24 \%$. For the X-ray diffraction [19] the graph form showed only the presence of crystalline compounds-calcium hydroxide and calcium carbonate-which are characteristic for lime $[38,46]$.

White cement was chosen with the main purpose of increasing the mechanical and fire characteristics of the new composite materials, but at the same time to offer a proper aesthetic side. The Portland white cement CEM I 52.5 produced by Devnya Cement was used, according to the BSS EN 197-1:2011. The cement powder is characterized by a white color, with a more intense brightness than the hydrated lime, seen when comparing Figure 3d with Figure 3a. The microscopic representation for the white cement powder was captured at the scale of $500 \mu \mathrm{m}$, shown in Figure 3e. The decomposition process of the cement powder was determined with the thermal analysis investigation. The maximum percentage of lost mass by the samples was $4.35 \%$. The degradation process was defined by three temperature intervals: $0-240{ }^{\circ} \mathrm{C}(1.08 \%), 240-500{ }^{\circ} \mathrm{C}(0.70 \%)$ and $500-1000{ }^{\circ} \mathrm{C}(2.56 \%)$. The X-ray diffraction [19] indicated high contents of $\mathrm{CaO}$ and $\mathrm{SiO}_{2}$, which define the main crystalline compounds of the cement-tricalcium silicate and dicalcium silicate-while the $\mathrm{Al}$ is found in small quantities, which determine the presence of the mineralogical compound of tricalcium aluminate, confirmed also by References [47-50]. Also, the X-ray diffraction of the white cement captures the presence of $\mathrm{TiO}_{2}$, which is responsible for the white pigment of the Portland cement [47]. 


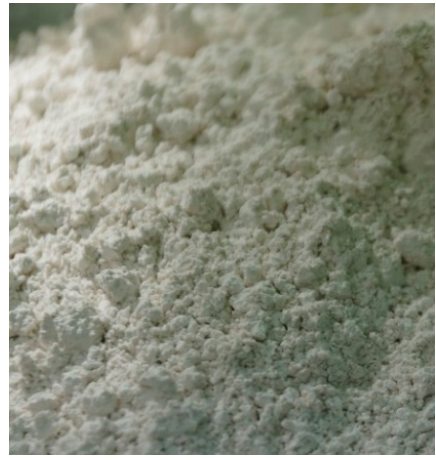

(a)

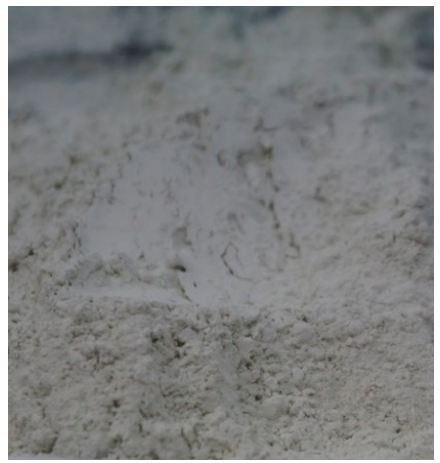

(d)

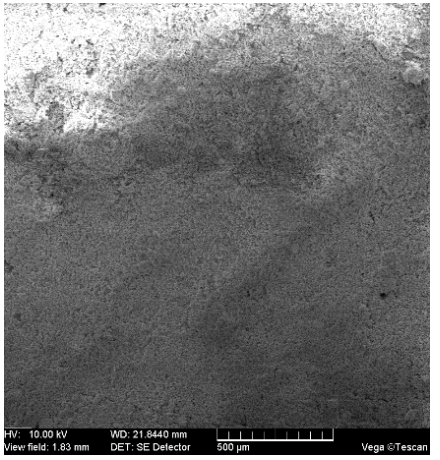

(b)

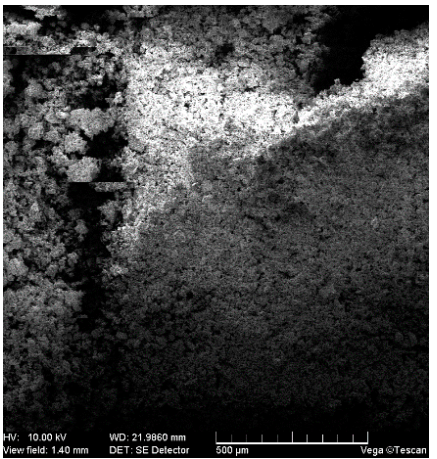

(e)

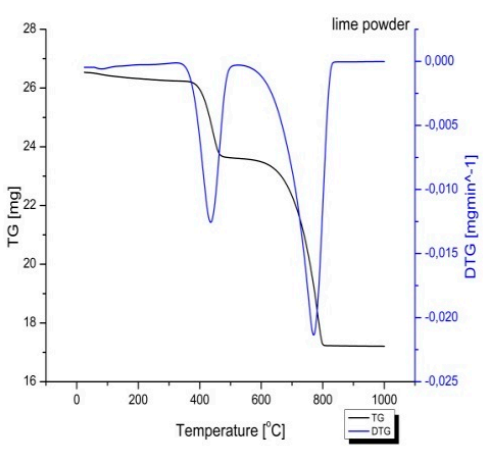

(c)

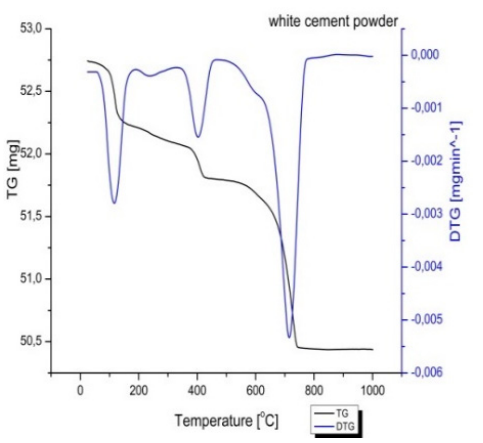

(f)

Figure 3. Binders (a) lime powder; (b) lime microscopy; (c) lime thermal analysis; (d) white cement powder; (e) white cement microscopy; (f) white cement thermal analysis.

\subsection{Preparation of New Composite Materials}

The mixing proportions of the new mortars were set up based on a previous study [18]. The composition of the analyzed samples started from the standard cement mortar formula. The sand grains were replaced with hemp shiv, obtaining three new compositions with a different hemp shiv volumes. The conclusion of the previous paper showed that the mix with a higher quantity of hemp has better acoustical and thermal characteristics. Therefore, to improve the obtained characteristics of this composition, a new set of recipes was analyzed. The new element introduced in the mortar mix was the volcanic rock, aiming to increase the fire properties of the materials, but also to obtain a lighter structure. Two types of volcanic rocks were proposed; perlite and vermiculite. Based on these new elements, three different compositions were analyzed, according to Table 1.

Table 1. Mixing proportion.

\begin{tabular}{lccc}
\hline $\begin{array}{c}\text { Identification Name in the Text } \\
\text { Composition Name }\end{array}$ & $\begin{array}{c}\mathbf{M} \mathbf{1} \\
\mathbf{C}+\mathbf{C}_{\mathbf{3}}+\mathbf{P}_{\mathbf{2}}\end{array}$ & $\begin{array}{c}\mathbf{M} \mathbf{2} \\
\mathbf{C}+\mathbf{C}_{\mathbf{3}}+\mathbf{V}_{\mathbf{2}}\end{array}$ & $\begin{array}{c}\mathbf{M} \mathbf{3} \\
\mathbf{C}+\mathbf{C}_{\mathbf{3}}+\mathbf{P V}_{\mathbf{2}}\end{array}$ \\
\hline \multicolumn{1}{c}{ Ratio by Volumes } & & & \\
\hline White cement (C) & 1 & 1 & 1 \\
Hemp shiv (C) & 3 & 3 & 3 \\
Perlite (P) & 2 & - & 1 \\
Vermiculite(V) & - & 2 & 1 \\
Water & 1 & 1 & 1 \\
\hline
\end{tabular}

The dosages of the three mixtures are expressed in volumes. The ratio between binder and hemp was 1:3, the cement to volcanic rocks ratio was $1: 2$ and the binder to water ratio was 1:1. The mixing sequence followed the traditional part of mortar recipe, by adding the volcanic rocks at the end of 
the process. Mixing was performed with a mechanical mixer. The composition was placed into the molds in a single layer and manually compacted. For each determination, different molds were used as required by the test procedure. The samples were kept in the molds for $24 \mathrm{~h}$ in laboratory conditions with a temperature of $24{ }^{\circ} \mathrm{C}$ and a humidity of $40 \%$. The three compositions were tested after 28 days.

\subsection{Visual Analysis}

The visual aspect of the compositions is shown in Figure 4. The mixtures present as homogeneous, with a uniform distribution of hemp fibers. Being designed for building interior mortars, white cement was chosen as a binder in order to comply with the aesthetic requirements. The compositions have different shades, depending on the volcanic rock used; therefore, the perlite compositions have a lighter shade than those with vermiculite, which, due to the mica appearance of the rock, are defined by a brown color.

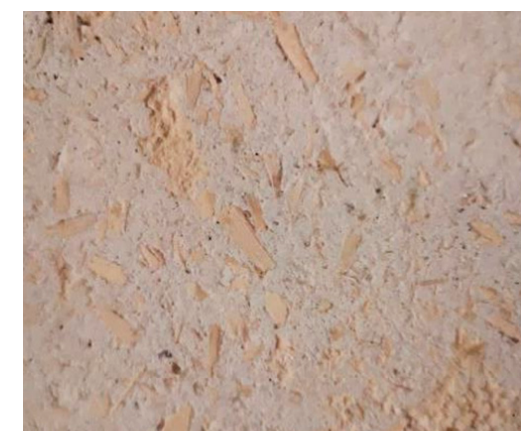

(a)

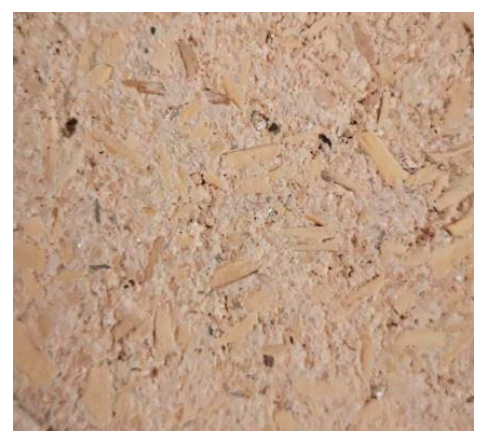

(b)

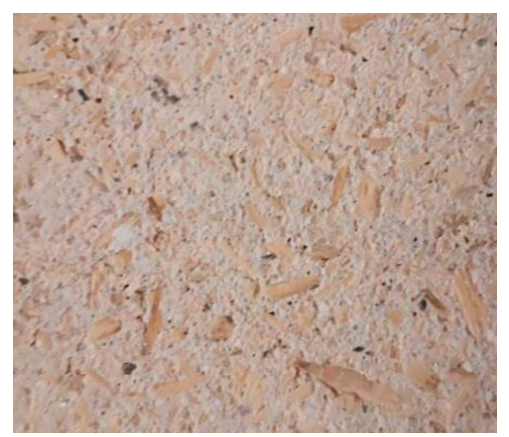

(c)

Figure 4. Visual composition (a) $M 1\left(C+C_{3}+P_{2}\right)$; (b) $M 2\left(C+C_{3}+V_{2}\right)$; (c) $M 3\left(C+C_{3}+P_{2}\right)$.

\subsection{Chemical Characterization}

The modal composition of the samples was determined by using a non-destructive method called X-ray diffraction. The technique was helpful in the identification and quantification of crystalline compounds. The samples were analyzed in the form of powder. The method consisted of recording the reflected radiation after the propagation of $X$-rays on the surface of the sample with a fixed wavelength and intensity. Depending on the arrangement of the atoms in the structure, the materials were classified into crystalline and noncrystalline compositions. The crystallinity of the materials is given if the atoms are disposed of in a repeated way over large atomic distances while the amorphous compounds are defined by a random display of the atoms [51]. The crystallinity of the samples was measured using a Shimadzu 6000 XRD diffractometer. The diffraction angle used was between $2 \theta=10-70^{\circ}$ and the applied wavelength was equal to $\lambda=1.54182 \AA$.

\subsection{Morphological Analysis}

The microstructural morphology of the samples was evaluated with a Scanning Electron Microscope, model VEGA, and with the software Tescan. The samples were broken into small pieces and, before the scanning process, they were sputter-coated with a layer of gold, with a thickness of 10nm, using the turbo molecular pumped coating system Q150T ES.

\subsection{Thermogravimetry Analysis}

The thermal analysis of the composite materials was proposed due to the fact that the ratio between hemp and binder was 3:1. The large volume of hemp from the compositions required more attention on the pyrolitic behavior of the existing biomass. Thermogravimetry analysis (TGA) is a method which presents the modifications in materials, both at physical or chemical levels, due to the change of temperature [52]. The analysis was carried out using a TGA/SDTA 851e_METTLER TOLLEDO device. 
The samples were tested in a nitrogen atmosphere (N2), at a gas flow rate of $60 \mathrm{~mL} / \mathrm{min}$ and a heat rate of $20^{\circ} \mathrm{C} / \mathrm{min}$ in the temperature range of $25-1000{ }^{\circ} \mathrm{C}$. The analysis was performed using $10 \mathrm{mg}$ of each composition.

\subsection{Bending Core Cohesion}

The fire behavior of the samples was determined using the method of bending core cohesion according to SR EN 520/A1:2010. The method consists of applying a bending moment to the sample while the lateral surface is affected by the flames of two burners. By heating, the bending moment causes a flexion on the sample [53]. Samples were of $300 \times 45 \times 12.5 \mathrm{~mm}^{3}$ size. According to the test requirements the sample needs to maintain its structure during $15 \mathrm{~min}$ at a constant temperature of $950{ }^{\circ} \mathrm{C}$.

\subsection{Mechanical Properties}

The mechanical efficacy of the volcanic rocks in the composition of the composite materials was subject to flexural and compression forces. The tests showed the capacity of the materials to react to the action of exterior forces and were operated according to SR EN 196-1:2016 at 3, 7, 14 and 28 days [54]. The flexural strength was analyzed on samples with $40 \times 40 \times 160^{3}$ size, using an automatic flexural tensile tester L15 Controls. The samples tested for compressive strength were the remaining prisms after the flexural strength. The test was carried out with a hydraulic press of 250KN Tecnotest.

\subsection{Thermal Properties}

The thermal behavior of the composite based on hemp-volcanic rocks-cement was determined according to SR EN 12667:2002 [55]. The test was performed using a heat flow meter of type FOX 200 (TA Instruments). The thermal conductivity determination consisted of applying a variable heat flux to a sample measuring $150 \times 150 \times 30^{3}$, fitted between two plates. The report obtained after each sample test indicated the values of the thermal conductivity coefficient and thermal resistance.

\subsection{Acoustic Properties}

The sound absorption coefficient defines the capacity of the materials to quantify the dissipation energy of a sound. The acoustic measurements were made according to SR EN ISO 10534-2 [56], using the transfer function method with two microphones. The test was carried out with the help of the Kundt Impedance tube, on a range frequency from $50 \mathrm{~Hz}$ to $6400 \mathrm{~Hz}$. Two types of samples, of $28 \mathrm{~mm}$ and $100 \mathrm{~mm}$ diameter, were analyzed. For the low frequency range 0 to $1600 \mathrm{~Hz}$, the test was operated on the high diameter samples and for the high frequency range from 500 to $6400 \mathrm{~Hz}$, on the small diameter samples. The thickness of the samples was $30 \mathrm{~mm}$. According to Reference [41], the value of NRC- noise reduction coefficient can be calculated based on sound absorption coefficient. The arithmetic mean of the sound absorption coefficient on the standardized frequency ranges of $250 \mathrm{~Hz}, 500 \mathrm{~Hz}, 1000 \mathrm{~Hz}$ and $2000 \mathrm{~Hz}$ can be expressed with the following formula [57]:

$$
N R C=\frac{\alpha_{250}+\alpha_{500}+\alpha_{1000}+\alpha_{2000}}{4}[-]
$$

\section{Results and Discussions}

\subsection{Chemical Characterization}

The modal composition is presented in Figure 5. The X-ray diffraction testing involved the identification of crystalline compounds, characteristic to each composition. The analysis of materials based on hemp shiv, volcanic rocks and white cement shows that crystalline compounds from the initial non-hydrated phase were found inside the composition, but also new formations that appeared during the hydration process. 


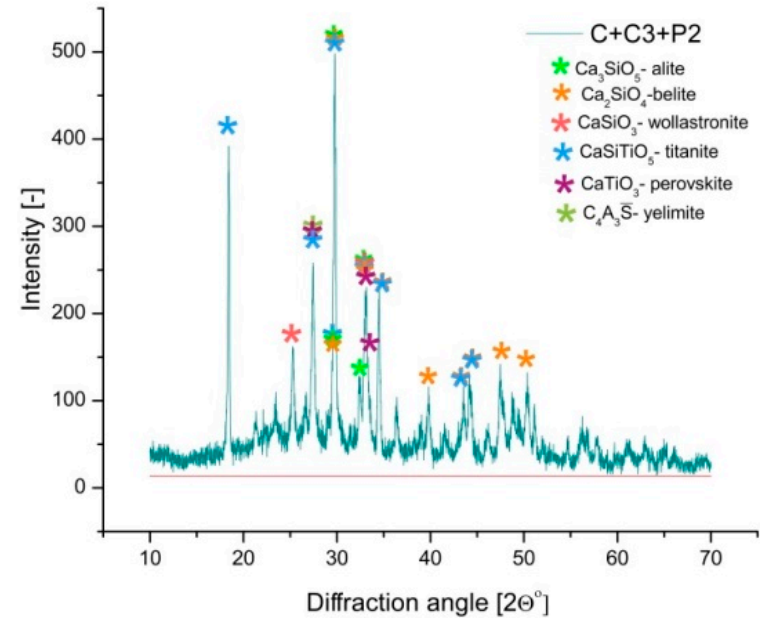

(a)

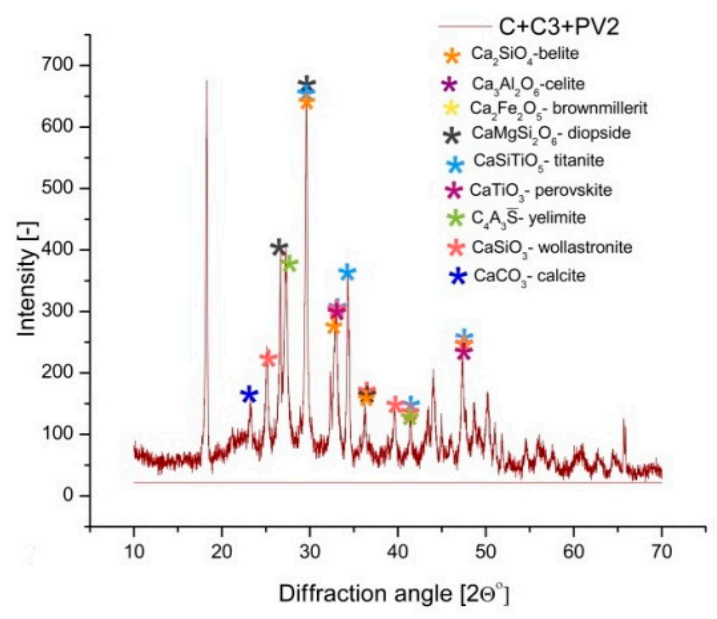

(c)

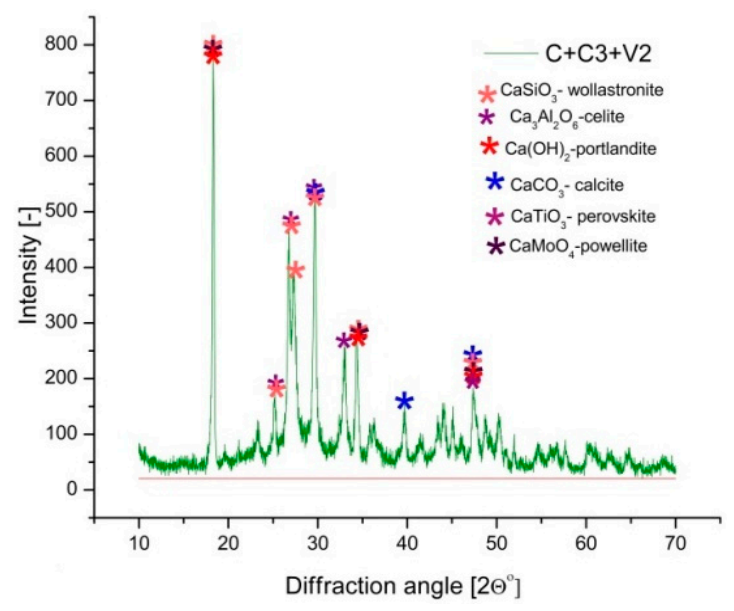

(b)

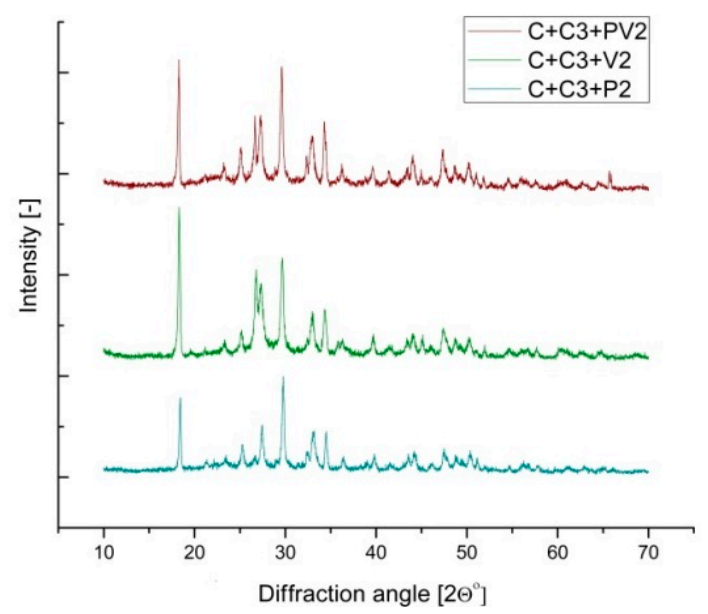

(d)

Figure 5. X-Ray diffraction (XRD) of the composite materials (a) $M 1\left(C+C_{3}+P_{2}\right)$; (b) $M 2\left(C+C_{3}+V_{2}\right)$; (c) $\mathrm{M} 3\left(\mathrm{C}+\mathrm{C}_{3}+\mathrm{PV}_{2}\right)$; (d) comparative analysis.

The main compounds found in the three materials were alite, belite, celite, portlandite, calcite, wollastronite, titanite, perovskite, powellite and yelimite. The first three compounds (alite, belite and celite) define the cement powder. Therefore, their identification in the composite samples can be related to the reduced amount of water during the hydration process. The ratio of water-cement used was 1:1, while the ratio of raw materials (hemp + rocks) to binder was 5:1. The explanation could be emphasized by the fact that the volume of water in the composition was not used only for the hydration of the cement paste, but was also retained by the structure of the volcanic rocks and the hemp, which has a high level of absorption. Reference [37] confirmed that vermiculite and perlite, due to their exfoliated structure, require more water, though perlite is more absorbent that vermiculite. This fact can be related to Diagram 5 (b), of the composite M2, where the compounds of alite and belite were absent, which can demonstrate that the hydration process was more complete. The cement hydration leads to new crystalline formations. From the reaction of alite and belite with water, portlandite $\mathrm{Ca}(\mathrm{OH})_{2}$ and gels C-S-H calcium silicate hydrate are formed, and by the hydration of celite with gypsum, ettringite $3 \mathrm{CaO} \cdot \mathrm{Al}_{2} \mathrm{O}_{3} \cdot 3 \mathrm{CaSO}_{4} \cdot 32 \mathrm{H}_{2} \mathrm{O}$ is formed [58]. This information can be confirmed with the diagram of vermiculite composite where portlandite appears. The calcium carbonate $\mathrm{CaCO}_{3}$ present on the diagrams appears as a result of the aging process of the cement paste, the $\mathrm{X}$-ray analysis being performed one year after the casting of the compositions. The rest of the compounds found in the cement paste structure are wollastronite, dioside, titanite, perovskite, powellite, yelimite. Their 
occurrence can be explained by the hydration reactions through cement compounds, hemp and volcanic rock compounds. A common compound for the three mixtures is wollastronite $\mathrm{CaSiO} 3$ which is responsible for increasing the mechanical performances [59]. The titanite $\mathrm{CaSiTiO}_{5}$ and perovskite $\mathrm{CaTiO}_{3}$ are also present due to $\mathrm{TiO}_{2}$, contained in the white cement power and in the volcanic rocks. Diopside is a compound found in $\mathrm{M} 3$, shown in Figure $5 \mathrm{c}$, which has a monoclinic structure pyroxene mineral with a high melting point of $1391{ }^{\circ} \mathrm{C}$ [60]. The analysis of graphs M1, shown in Figure 5a, and M2, shown in Figure 5b, shows that the crystalline formations are different, but their compounds are found in mixture M3. From Figure 5d, by analyzing the peaks of the compositions, it can be shown that the structure of the M1 recipe is the one with the best contoured peaks.

\subsection{Petrographic Features}

The scanning electron microscopy (SEM) images of the three mixtures are presented in Figure 6. In order to have an overview of each microscopic structure of the composites, the SEM representations were taken to various scales, of $2 \mathrm{~mm}, 200 \mu \mathrm{m}, 50 \mu \mathrm{m}$, and $5 \mu \mathrm{m}$. The morphology of the composites presented at the $2 \mathrm{~mm}$ scale, shown in Figure $6 \mathrm{a}-\mathrm{c}$, showed a general texture in which the hemp fibers are incorporated in a binder matrix, while at the scale of $200 \mu \mathrm{m}$, the cracks on the surface of the composite are more visible and the images of volcanic rocks become more prevalent. The need to obtain a small piece of composite to perform this microscopic analysis determined the application of a breaking force on the structure of the composite, which could explain some of the cracks that appeared on the surface of the material. The hemp shiv has a tendency to fix itself to the cement matrix, due to the streaks given by the woody surface. Figure $6 \mathrm{f}$ presents the M2 composition at $200 \mu \mathrm{m}$, with the channels still visible, after the hemp detachment, supports the previous observation. At the same resolution, the compositions of M1, shown in Figure 6d, and M3, shown in Figure 6e, showed the porous texture of these materials, it being easy to associate the initial SEM images of the perlite, shown in Figure $2 b$, and vermiculite, shown in Figure $2 d$, with the images from the matrix of the composite materials. Increasing the scan resolution at $50 \mu \mathrm{m}$, (see Figure $6 \mathrm{~g}-\mathrm{i}$ ) allows a more accurate observation of the cement matrix covering the surface of the raw materials. The most interesting images were taken from scale $5 \mu \mathrm{m}$, (Figure 6j-1) showing the new structures obtained after the cement hydration. The cement hydration process is defined when the mix between the cement and water decrease the plasticity and increase the rigidity in the hardening stage [59]. The resulting compounds after the hydration of the composite materials are C-S-H gels, $\mathrm{CH}$ (portlandite or calcium hydroxide), ettringite, monosulfatem unhydrated, cement particles, air voids, according to References [61,62]. The first three compounds are responsible for the strength properties. The C-S-H gel has the role of filling in the pore space of the composite structures and is responsible for the strength and durability of the cement-based materials, by creating a reticular network between the cement molecules. The $\mathrm{CH}$ structure is represented by large crystals with hexagonal prism forms $[61,63,64]$, while the ettringite structure is similar to needle-shaped crystals [65]. The study showed [66] that the ratio of water/cement can also impact significantly the expansion of the new hydrated crystals. When the ratio is high-in our situation, it is 1:1-there is a considerable percentage of water and space in the structure of the composites, which allows the widespread development of the new crystals. At the scale of $5 \mu \mathrm{m}$, a large surface covered with acicular formations can be observed; different studies refer to them as ettringite crystals. The expansive surface of ettringite can be explained through Reference [65], which states that the formation of the crystals is due to the consumption of yelimite, anhydrite, gypsum, and $\mathrm{Ca}(\mathrm{OH})_{2}$. Some of these crystalline compounds were found in the X-ray diagrams of the new composites based on cement, hemp and volcanic rocks. 


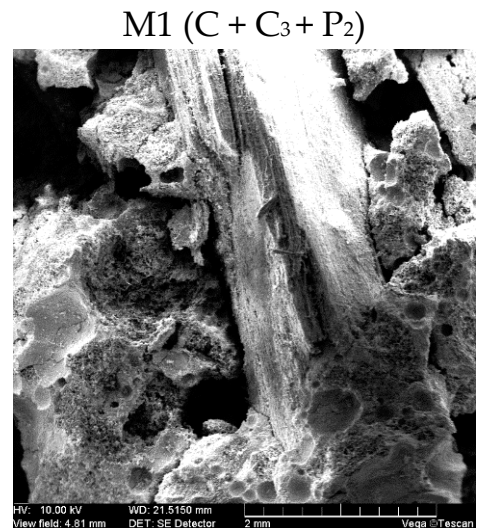

(a)

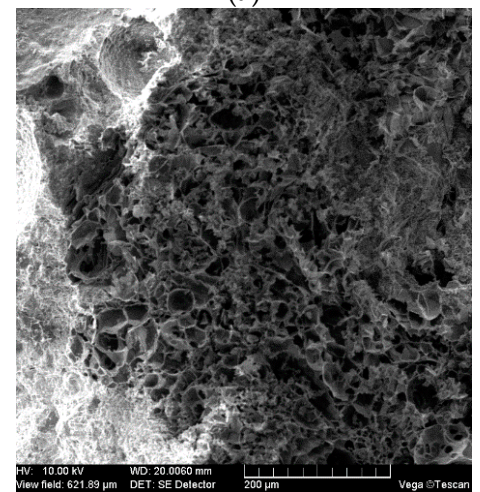

(d)

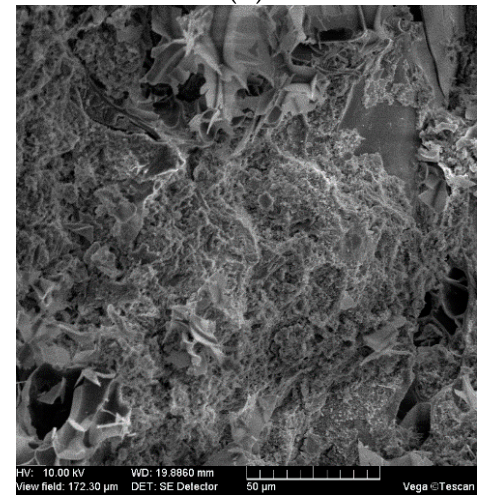

(g)

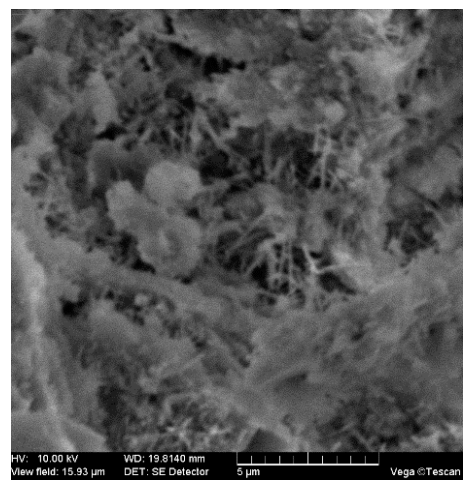

(j)

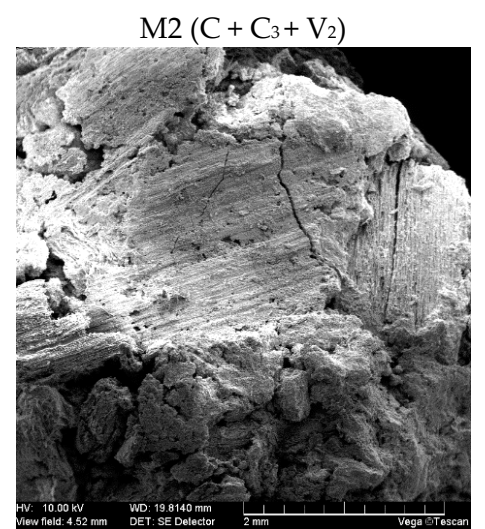

(b)

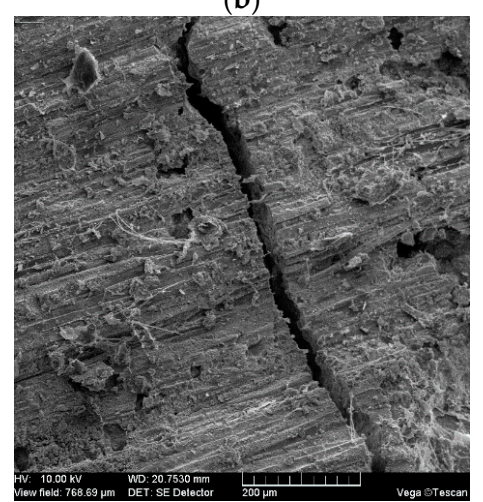

(e)

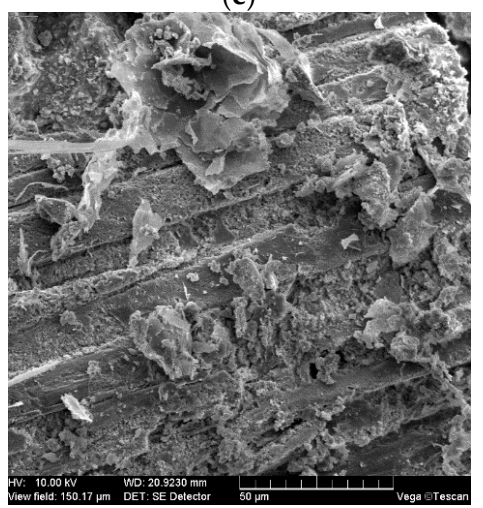

(h)

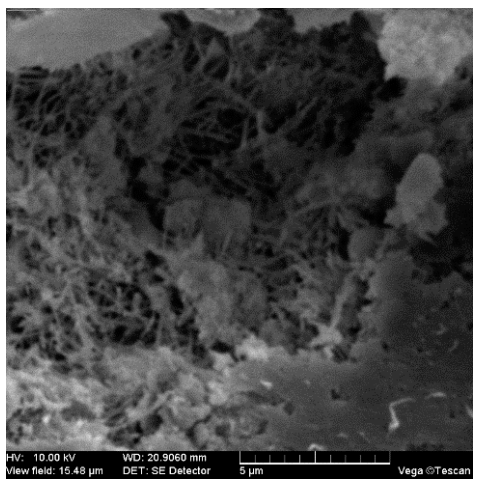

$(\mathbf{k})$

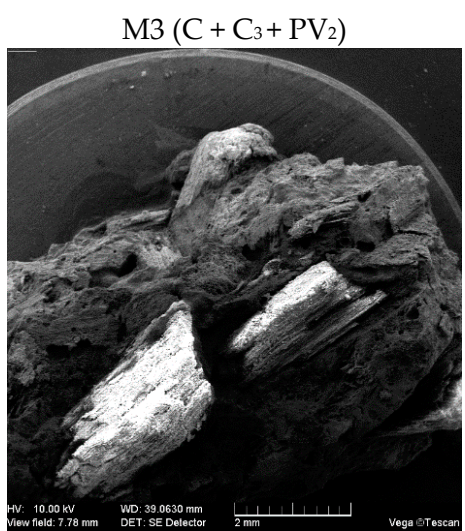

(c)

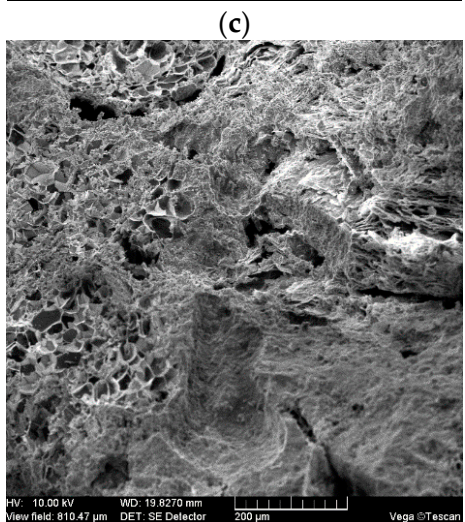

(f)

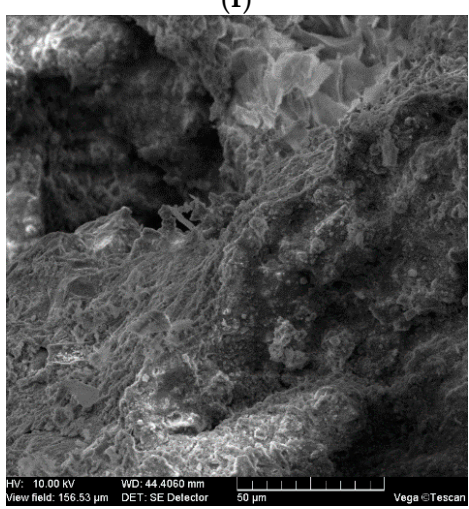

(i)

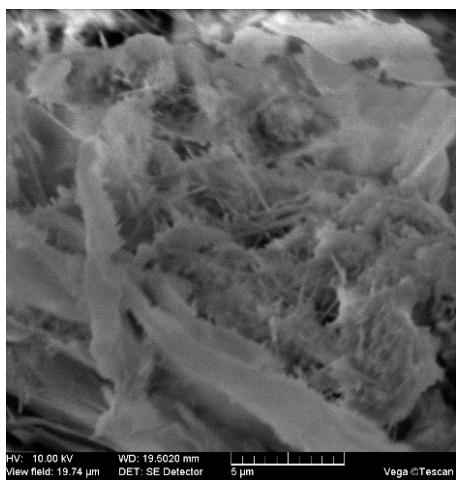

(1)

Figure 6. Scanning electron microscopy (SEM) of the composite materials at different scales at $2 \mathrm{~mm}$ $(\mathbf{a}-\mathbf{c}) ;$ at $200 \mu \mathrm{m}(\mathbf{d}-\mathbf{f}) ;$ at $50 \mu \mathrm{m}(\mathbf{g}-\mathbf{i})$ and at $5 \mu \mathrm{m}(\mathbf{j}-\mathbf{1})$. 


\subsection{Thermal Analysis}

The thermal behavior of the composites, based on hemp shiv, volcanic rocks and white cement, is presented in Figure 7a-c. A first observation of the diagrams refers to the curves representation, which shows a degradation rate around $1 \%$ between the three composites. The lowest degradation percentage is registered by the composition M2 with $31 \%$, followed by M3 with $32.63 \%$, and the highest percentage being obtained by M1 with $33.24 \%$, Figure $7 \mathrm{~d}$. In the degradation process, four temperature ranges were identified. Table 2 shows the amount of mass lost by each composite material, by temperature range.

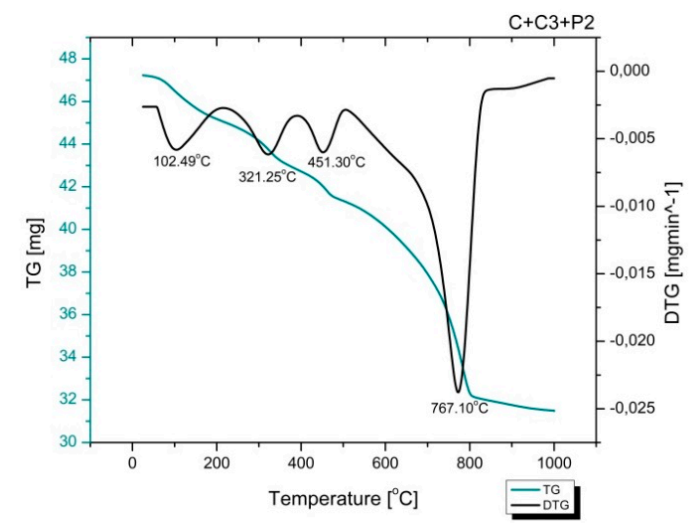

(a)

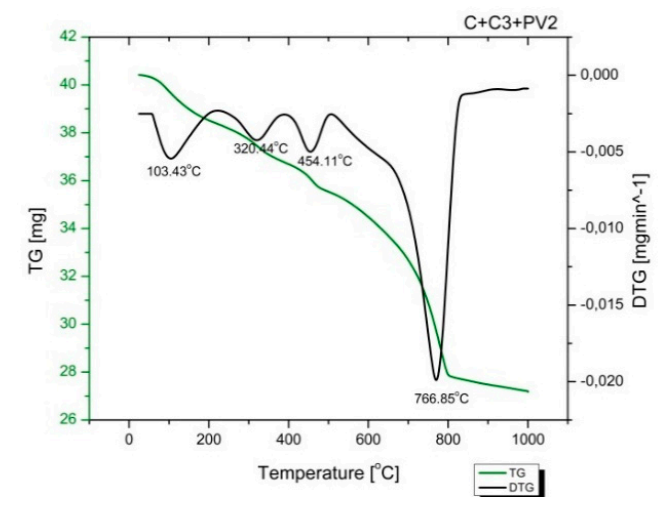

(c)

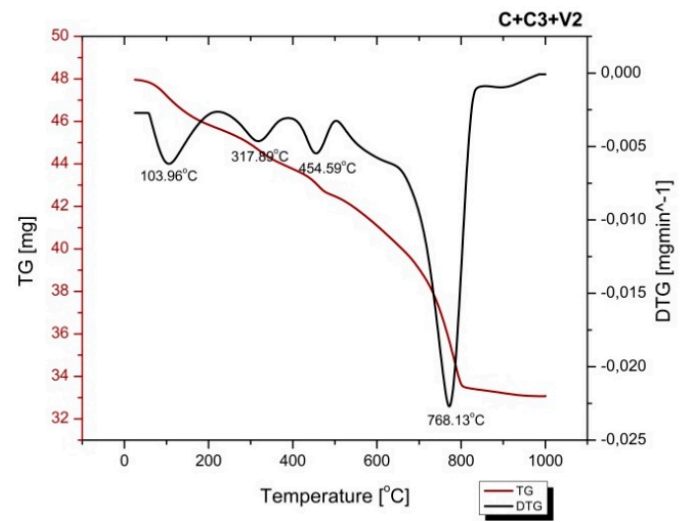

(b)

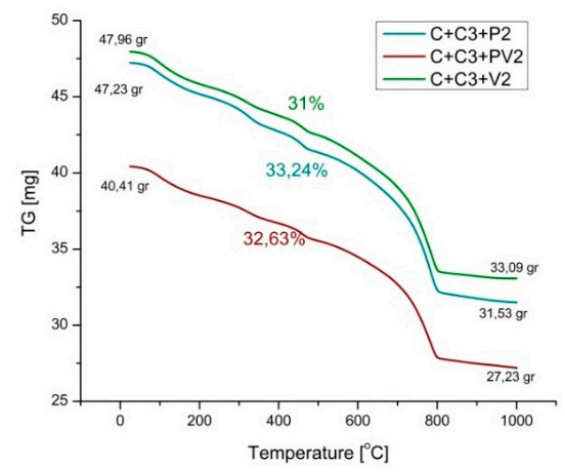

(d)

Figure 7. Thermal analysis of the composite materials (a) $M 1\left(C+C_{3}+P_{2}\right)$; (b) $M 2\left(C+C_{3}+V_{2}\right)$; (c) $\mathrm{M} 3\left(\mathrm{C}+\mathrm{C}_{3}+\mathrm{PV}_{2}\right)$; (d) comparative analysis.

Table 2. Mass loss of the composite.

\begin{tabular}{|c|c|c|c|c|c|c|}
\hline \multirow{2}{*}{$\begin{array}{c}\text { Composition } \\
\text { UM }\end{array}$} & \multicolumn{2}{|c|}{$\operatorname{M1}\left(C+C_{3}+P_{2}\right)$} & \multicolumn{2}{|c|}{$M 2\left(C+C_{3}+V_{2}\right)$} & \multicolumn{2}{|c|}{$\mathrm{M} 3\left(\mathrm{C}+\mathrm{C}_{3}+\mathrm{PV}_{2}\right.$} \\
\hline & $\%$ & mg & $\%$ & mg & $\%$ & mg \\
\hline & 100 & 47.23 & 100 & 47.93 & 100 & 40.41 \\
\hline $0-220^{\circ} \mathrm{C}$ & 4.63 & 2.19 & 4.71 & 2.26 & 4.98 & 2.01 \\
\hline $220-400{ }^{\circ} \mathrm{C}$ & 4.86 & 2.29 & 4.01 & 1.92 & 4.19 & 1.69 \\
\hline $400-500{ }^{\circ} \mathrm{C}$ & 2.94 & 1.39 & 2.69 & 1.29 & 2.86 & 1.15 \\
\hline $500-1000{ }^{\circ} \mathrm{C}$ & 20.80 & 9.82 & 19.06 & 9.40 & 20.57 & 8.31 \\
\hline total & 33.24 & 15.70 & 31.00 & 14.87 & 32.63 & 13.18 \\
\hline
\end{tabular}

The first temperature range $\left(0-220^{\circ} \mathrm{C}\right)$ is characterized by a loss of mass between $4.63 \%$ and $4.98 \%$ per composition, especially around the temperature of $103^{\circ} \mathrm{C}$. The highest percentage is attributed to M3. From $220^{\circ} \mathrm{C}$ to $400^{\circ} \mathrm{C}$, the mass loss was similar to the previous, with an exception-M1 degraded 
quicker, as shown in Figure 7a. On the third interval the maximum percentage loss was $2.94 \%$ for $\mathrm{M} 1$, at around $450{ }^{\circ} \mathrm{C}$. For the temperature range from 500 to $1000{ }^{\circ} \mathrm{C}$ there was approximately a $20 \%$ mass loss at the temperature of $767^{\circ} \mathrm{C}$. According to the scientific literature, the thermal analysis of the cement paste is characterized by the discomposure of ettrinigite at a temperature of $120-130{ }^{\circ} \mathrm{C}$, the C-S-H gel below $150{ }^{\circ} \mathrm{C}$, the non-hydrated gypsum at about 140 to $170{ }^{\circ} \mathrm{C}$ and $\mathrm{CH}$ (portlandite) between 420 and $550{ }^{\circ} \mathrm{C}$ [67]. Reference [28] presented the thermal behavior of the hemp shiv treated with $\mathrm{CaOH}_{2}$ (lime solution) and identified two temperature ranges for the degradation, the first one around $337^{\circ} \mathrm{C}$ - when the depolymerisation of hemicellulose or pectin took place-and the second one, between $377-399^{\circ} \mathrm{C}$, when the cellulose decomposition occurred.

The perlite thermal decomposition presented in Reference [68] is defined by two stages, up to $120^{\circ} \mathrm{C}$ the volcanic rock loses the water, and before $600^{\circ} \mathrm{C}$ the dehydroxylation process occurs. Vermiculite, according to Reference [69], loses the water molecules under $127^{\circ} \mathrm{C}$. After that, it releases the hydroxyl from the interlayers. An observation of the four temperature ranges for the above mentioned composite materials in correlation with the scientific literature is that from $0-220^{\circ} \mathrm{C}$ the composite mortars lose the water molecules, which affects the decomposition of the ettringite, $\mathrm{CSH}$ and non-hydrated gypsum. From 220 to $400{ }^{\circ} \mathrm{C}$, the hemp shiv is decomposed by losing cellulose and hemicellulose. From 400 to $500{ }^{\circ} \mathrm{C}$ the portlandite crystals disappear and from 500 to $1000{ }^{\circ} \mathrm{C}$ the volcanic rocks release the hydroxyl groups.

\subsection{Bending Core Cohesion}

The composite materials were tested for bending core cohesion and the results complied with the test requirements, as shown in Figure $8 \mathrm{~b}$. The samples were tested at their thickness real scale, considered as prefabricated plates. The materials were embedded in a device in which the side faces were positioned between two burners, as shown in Figure 8a. After $15 \mathrm{~min}$, at a temperature of $950{ }^{\circ} \mathrm{C}$, the three compositions remained intact. The opening produced by the flame was $7.4 \mathrm{~cm}$ for $\mathrm{M} 1,7 \mathrm{~cm}$ for M2 and $6.5 \mathrm{~cm}$ for M3, according to Figure 8c. Positioned vertically (see Figure 8d) the samples show the degree of fire penetration inside the material. Therefore, it can be noticed that the sample with hemp-perlite-vermiculite is more resistant due to the fact that the fire penetration is less expanded comparative with the other samples. The most damaged sample was the perlite composition.

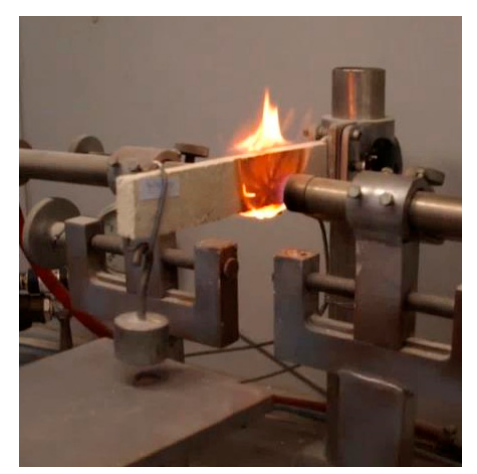

(a)

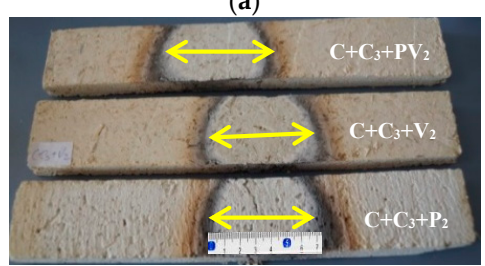

(c)

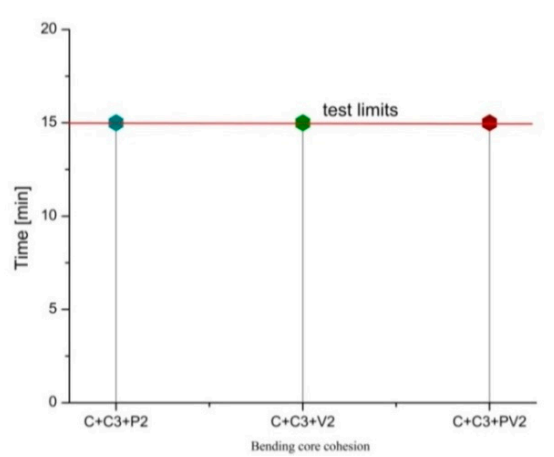

(b)

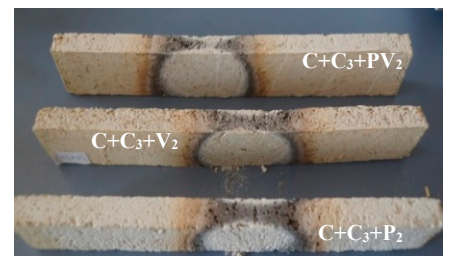

(d)

Figure 8. Bending core cohesion of the materials (a) testing device; (b) graphic results; (c) horizontal faces of the samples; (d) vertical faces of the samples 


\subsection{Mechanical Properties}

The results of the flexural and compressive strengths are presented in Figure 9a,b. The tests were performed at 3, 7, 14 and 28 days, with the flexural strength device, shown in Figure 9c and the hydraulic press, shown in Figure 9d, for compressive strength.

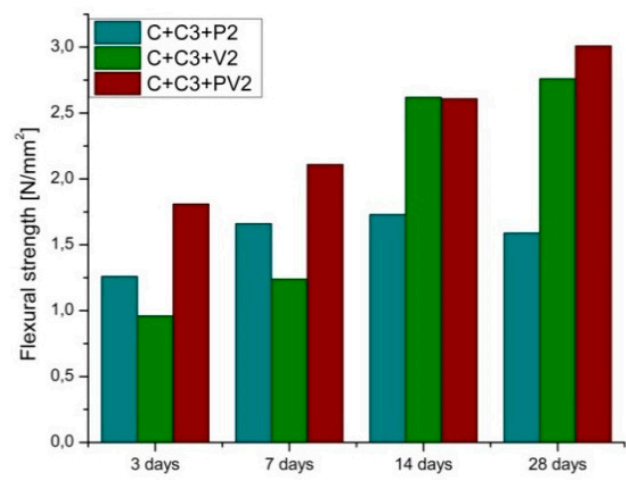

(a)

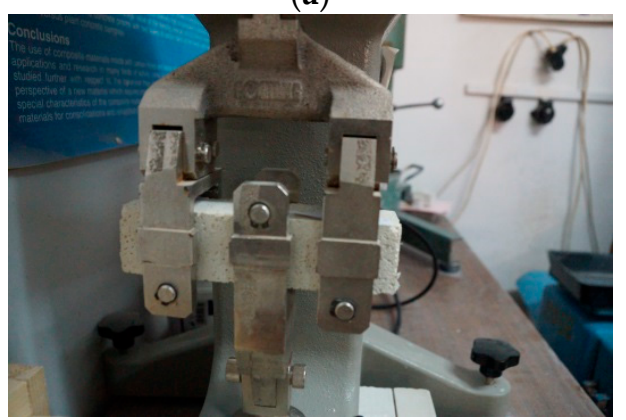

(c)

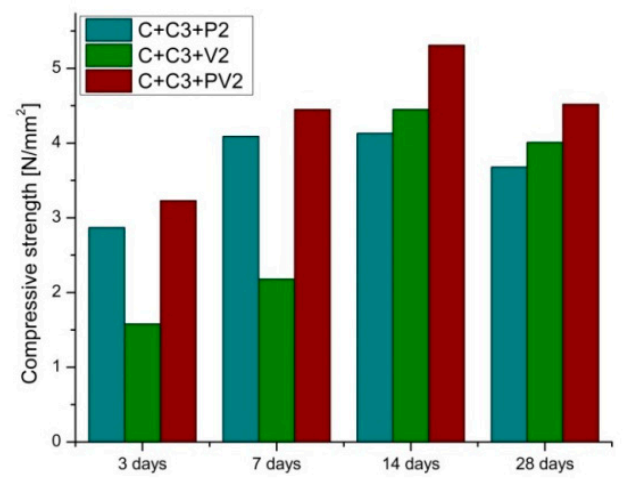

(b)

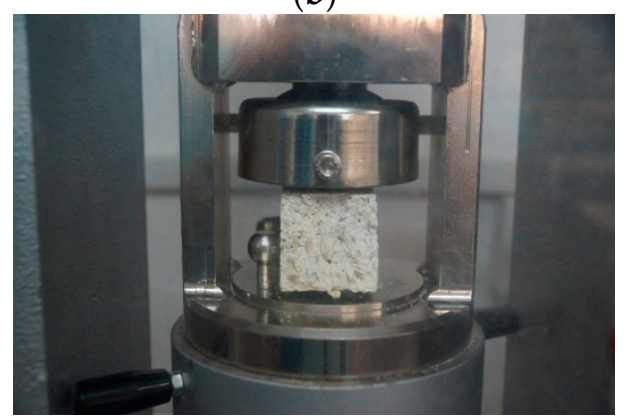

(d)

Figure 9. Mechanical properties (a) flexural strength; (b) compressive strength; (c) flexural strength device; (d) hydraulic press.

For the flexural strength, the three composites show values between $1.6-3 \mathrm{~N} / \mathrm{mm}^{2}$, while for the compressive strength the values are between 3.69 and $4.53 \mathrm{~N} / \mathrm{mm}^{2}$. As a general observation, the results obtained were lower than the standard cement mortar values, because of the hemp shiv and volcanic rocks incorporated in the matrix of the new elements. reference [37] states that the air from the pores of the volcanic rocks is responsible for the decrease in the mechanical properties of the new materials. Another aspect is that the hemp and volcanic rocks absorb the water, but do not react to it, so the only element that creates bonds and connects all raw materials is the cement [37]. There is a continuous increase of the compressive and flexural strengths during the tests. A common observation related to the mechanical resistances refers to the impact of the volcanic rocks upon the structure of the composites. M1 sample evolves the least, the values recorded being close to one another. There is a slight gradual increase at 3, 7 and 14 days, followed by a decrease at 28 days, although the difference is not particularly significant. The decreased values obtained for compressive strength at 28 days may be explained by the environmental conditions. Due to this fact the hemp-based materials were designed as prefabricated plates, and the investigated samples were kept in laboratory conditions. The porous volcanic rocks from the samples, absorbed more water, which affected the proper hydration of the cement until 28 days In contrast, M2 has a relatively small increase in values between 3 and 7 days, after which the resistance, both at bending and at compression, doubles at 14 days. At 28 days, the value of the bending resistance increases compared to 14 days value, while the compression strength values decrease. Using both perlite and vermiculite in M3 exhibits an improvement of the mechanical strengths, the flexural and compression values registering a constant increase with similar 
or higher values compared to the other two compositions. An explanation on the performances of perlite and vermiculite composites could be shown in the X-ray analysis, where the crystal compound of diopside was identified. According to Reference [45], diopside presented a lower degradation rate and increased the mechanical performances. The hemp shiv size can be also taken into consideration for the poor values of the mechanical strength, as References $[70,71]$ showed that, the finer the hemp shiv particles, the stronger the boundaries around the fibers created by the binder will be, and the higher the mechanical characteristics of the composite. The values obtained for the compressive strength are similar to those in Reference [72].

\subsection{Thermal Properties}

The thermal properties of the composite materials are defined by bulk density, thermal conductivity and thermal resistance. The thermal conductivity and the thermal resistance were investigated using the Fox 200, Figure 10a, while for the bulk density of the samples, their mass was divided by their volume. The bulk density of the materials is between 600 and $750 \mathrm{~kg} / \mathrm{m}^{3}$, Figure 10b, the thermal conductivity varies between 0.124 to $0.162 \mathrm{~W} / \mathrm{mK}$, Figure 10c and thermal resistance values are between 0.189 and $0.244 \mathrm{~m}^{2} \mathrm{~K} / \mathrm{W}$, Figure $10 \mathrm{~d}$.

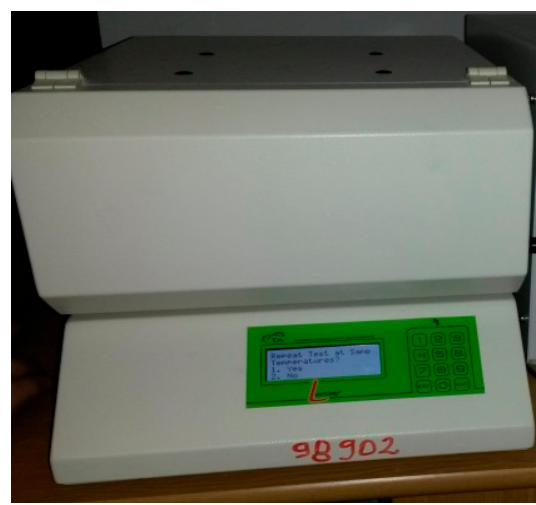

(a)

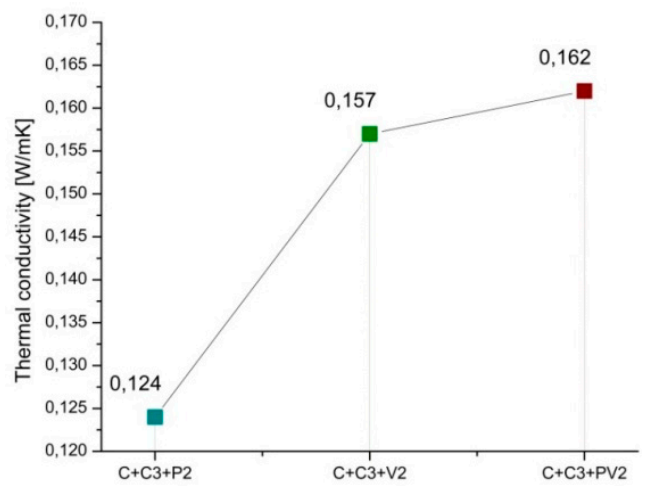

(c)

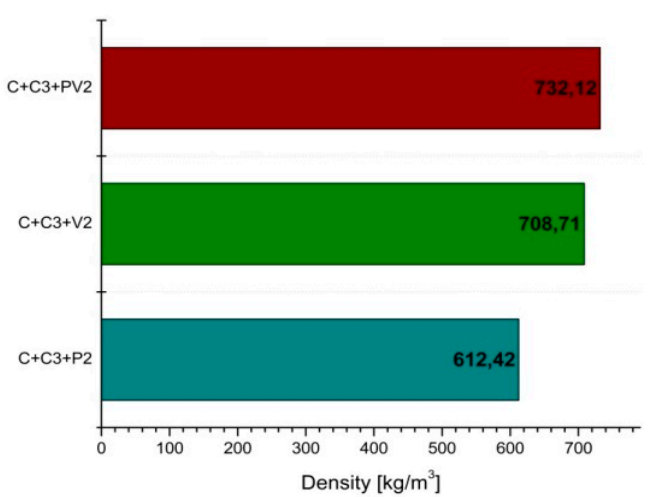

(b)

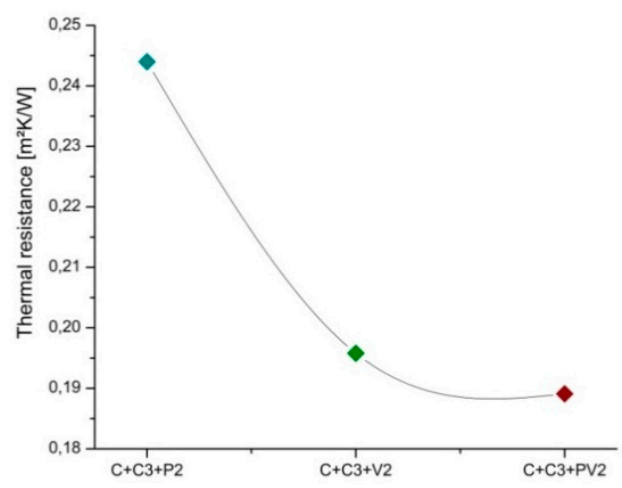

(d)

Figure 10. Thermal properties (a) device; (b) density; (c) thermal conductivity; (d) thermal resistance

Due to the fact that the compositions are expressed in volumes, the differences that occur are based on the type of volcanic rock used. In the pre-testing phase, the density of the two types of rocks was determined. The results show that perlite was lighter than vermiculite, based on the values obtained $\left(130 \mathrm{~kg} / \mathrm{m}^{3}\right.$ for perlite, $140 \mathrm{~kg} / \mathrm{m}^{3}$ for vermiculite). Therefore, the best thermal performance is recorded by M1 with $0.124 \mathrm{~W} / \mathrm{mK}$ and a density of $612 \mathrm{~kg} / \mathrm{m}^{3}$ compared to M2. The same observation was made also in Reference [73]. The values of the thermal conductivity are directly proportional to the density of the materials, while the thermal resistance is inversely proportional to the thermal conductivity. 
The M3 composition shows a lower density than that of M2, which can be related to the different particle size distribution of both fillers. Further investigation on the particle size distribution of these rocks should be carried out. The addition to volcanic rocks in hemp-cement mortar compositions results in an increase of thermal performance, to around 50\% [18]. In the analysis of their mechanical strengths compared to the thermal performance of the materials one can see that the addition of perlite increases the thermal performance of a material and at the same time decreases the values of mechanical strength. A consideration regarding the improvement of the thermal properties could be connected to the mixing process, according to Reference [73]. If mixing time is increased, the volcanic rocks are broken, which will increase the density and decrease the value of the thermal conductivity. Regarding the influence of the hemp in the compositions, it can be considered that using a smaller dimension of the wood fibers will grow the thermal properties due to the fact that the materials will be defined by a finer porous structure [72].

\subsection{Acoustic Properties}

The acoustic properties of the new composite materials are defined by the sound absorption coefficient according to the frequency range between $0-6400 \mathrm{~Hz}$; they are tested using the Kundt tube, as shown in Figure 11a.

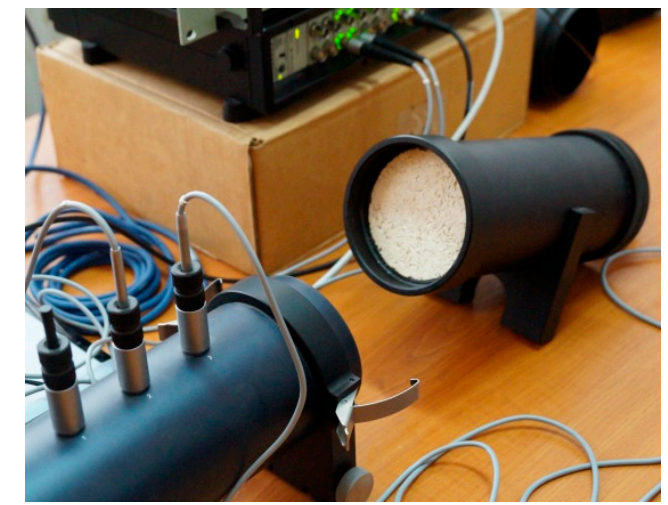

(a)

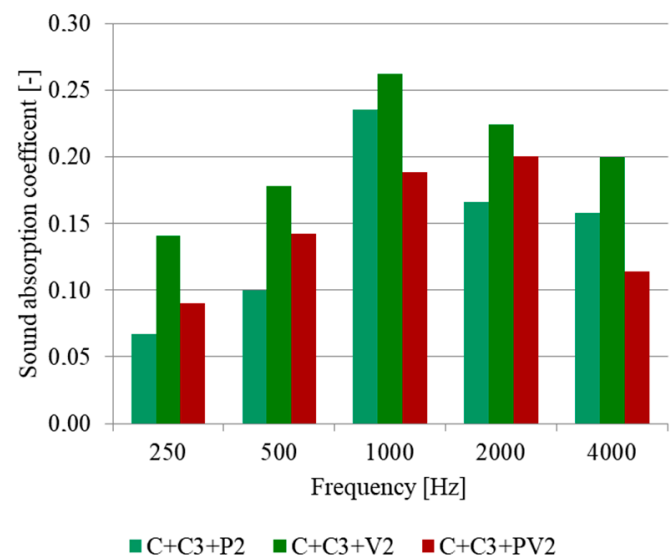

(c)

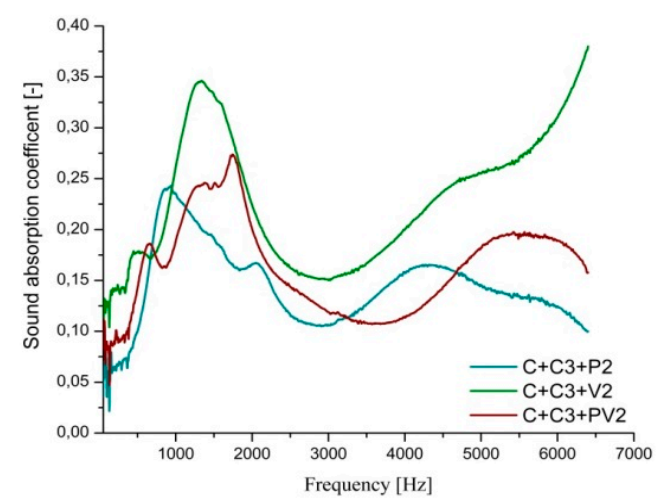

(b)

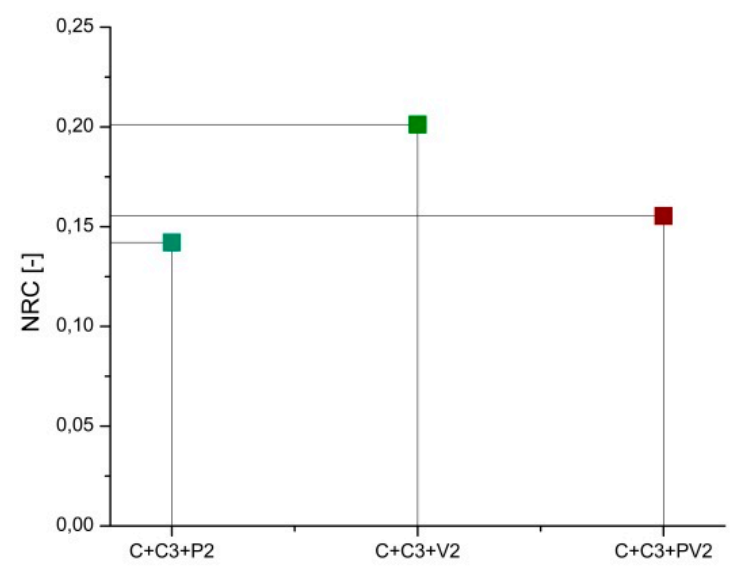

(d)

Figure 11. Acoustic properties (a) Kundt tube; (b) sound absorption coefficient 0-6400 Hz; (c) sound absorption coefficient on frequency standard bands; (d) noise reduction coefficient graph

The sound absorption coefficient is defined by the absorbed and incident sound energy [74]. The diagrams of the sound absorption coefficients on a frequency range from 0 to $6400 \mathrm{~Hz}$ are presented in Figure 11b. The capacity of a material to absorb the sound is defined by the type of binder, 
its percentage, the size of the raw materials and the thickness of the new material [75]. The data obtained after the measurements, shown in Figure 11b, showed that the maximum value of sound absorption from the three composites is around 0.35 on a frequency of around $1500 \mathrm{~Hz}$, for M3. Analyzing the sound absorption coefficient on the standard frequency bands, show in Figure 11c, one can see that M1 and M2 gradually increase sound absorption up to $1000 \mathrm{~Hz}$ and then they reduce it. Composite M3 presents increasing values until $2000 \mathrm{~Hz}$ followed by almost 0.1 , on the last frequency standard band Figure $11 \mathrm{~d}$ shows the noise reduction coefficient which confirms that the most absorbent sample is defined by M2 because of its higher porous structure confirmed through the SEM images, shown in Figure 2b,d. Less absorbent are M3 and M1. This is confirmed by Reference [76], that smaller particles increase the reflection and larger particles increase the attenuation and reduce the reflection. Comparing these results with other studies [77] it was remarked that the sound absorption coefficient depends on the particle size of the hemp and the type of binder. The cement is regarded as a reflexive binder; thus hemp and volcanic rocks will have the main role in the absorption of the sound. At the same time, increasing the volume of binder, which has low mechanical properties, will negatively influence the porosity and will decrease sound absorption. The size of the hemp shiv can influence the sound absorption coefficient of the material: if the size of the hemp shiv is smaller, the sound absorption will increase [77]. Considering all the information found in the scientific literature regarding the size of the particles, the binder, the thickness of the composite, and the air gap, further research shall be carried out in order to analyze all the parameters that influence the sound absorption coefficient of the new industrial crops composites.

\section{Conclusions}

The new hemp shiv, volcanic rock and cement based mortars studied in this paper were designed to respond to sustainable conditions, but also to increase indoor comfort performance. The main conclusions resulting from the study are:

- The X-ray diffraction helped interpret the hydration process of the cement related to the raw materials;

- The SEM images showed new crystalline bonds that formed in the composition of the new hemp based materials;

- The thermal analysis revealed that, by adding vermiculite to the composition, the degradation of the composites at higher temperature will be slowed down;

- For the fire behavior, the presence of perlite and vermiculite increased the fire resistance of the organic material;

- The mechanical characteristics of the materials are especially defined by the ratio of the binder with water and binder with raw materials. The best performing composite for flexural and compressive strength is the one based on perlite and vermiculite;

- The thermal conductivity is related to the bulk density of the composite. Increasing the pore structure of a material will contribute to a lower density, which will lead to a decreased value of the thermal conductivity. By using perlite in the composites the value of the thermal conductivity will decrease;

- In terms of sound absorption coefficient, the presence of vermiculite in the mixtures increases the acoustic performance of the new composite materials.

Author Contributions: Conceptualization, R.I.; methodology and investigation, R.I., D.R.T.-G., D.L.M.; writing-original draft preparation, R.I.; writing-review and editing R.I., D.R.T.-G.; funding acquisition, D.R.T.-G. All authors have read and agreed to the published version of the manuscript.

Funding: The results presented in this paper were obtained in the framework of the GNaC 2018 ARUT grant "Innovative solutions for the acoustic comfort in open space offices", research Contract no. 3223/06.02.2019, with the financial support of the Technical University of Cluj-Napoca.

Conflicts of Interest: The authors declare no conflict of interest. 


\section{References}

1. Tuladhar, R.; Yin, S. Sustainability of Using Recycled Plastic Fiber in Concrete; Elsevier Ltd.: Amsterdam, The Netherlands, 2019.

2. Maria, C.; Andreş, D.; Manea, D.L. Using Wheat Straw in Construction. Available online: https://www.google. com.hk/url?sa=t\&rct=j\&q=\&esrc=s\&source=web\&cd=1\&ved=2ahUKEwiu9fT668XnAhXFdd4KHSR_ CwQQFjAAegQIAhAB\&url=http\%3A\%2F\%2Fjournals.usamvcluj.ro\%2Findex.php\%2Fpromediu\% 2Farticle\%2Fdownload\%2F11216\%2F9198\&usg=AOvVaw0myBXdWhQ_o3NqZBIMrblK (accessed on 10 February 2020).

3. Jami, T.; Karade, S.R.; Singh, L.P. A review of the properties of hemp concrete for green building applications. J. Clean. Prod. 2019, 239, 117852. [CrossRef]

4. Tamas-Gavrea, D.-R.; Istoan, R.; Tiuc, A.E. Multilayered Composite Panel and the Method Used for Obtaining it. Patent Application No. A00288, 24 April 2018.

5. Hamard, E.; Cazacliu, B.; Razakamanantsoa, A.; Morel, J. Cob, a vernacular earth construction process in the context of modern sustainable building. Build. Environ. 2016, 106, 103-119. [CrossRef]

6. Dénes, O.; Florea, I.; Manea, D.L.; Afonso, P. Utilization of sheep wool as a building material. Procedia Manuf. 2019, 32, 236-241. [CrossRef]

7. Petrounias, P.; Giannakopoulou, P.P.; Rogkala, A.; Lampropoulou, P.; Tsikouras, B.; Rigopoulos, I. Petrographic and Mechanical Characteristics of Concrete Produced by Different Type of Recycled Materials. Geosciences 2019, 9, 264. [CrossRef]

8. Abdallah, S.; Fan, M. Characteristics of concrete with waste glass as fine aggregate replacement. Int. J. Eng. Technol. Res. 2014, 2, 6.

9. Tiuc, A.B.; Rusu, T.; Vasile, O. Investigation Composite Materials for its Sound Absorption Properties. Available online: https:/www.researchgate.net/publication/258212172_Investigation_composite_materials_ for_its_sound_absorption_properties (accessed on 10 February 2020).

10. Bedlivá, H.; Isaacs, N. Hempcrete-An environmentally friendly material ? Adv. Mater. Res. 2014, 1041, 83-86. [CrossRef]

11. Hamzaoui, R.; Guessasma, S.; Abahri, K. Mechanical Performance of Mortars Modified with Hemp Fibres, Shives and Milled Fly Ashes. Available online: https://www.researchgate.net/publication/319879827_ Mechanical_performance_of_mortars_modified_with_hemp_fibres_shives_and_milled_fly_ashes (accessed on 10 February 2020).

12. Hirst, E.A.J. Characterisation of Hemp-Lime As a Composite Building Material. Available online: https://researchportal.bath.ac.uk/en/publications/characterisation-of-low-density-hemp-limecomposite-building-mate (accessed on 10 February 2020).

13. Mazhoud, B.; Collet, F.; Pretot, S.; Chamoin, J. Hygric and thermal properties of hemp-lime plasters. Build. Environ. 2016, 96, 206-216. [CrossRef]

14. Kinnane, O.; Reilly, A.; Grimes, J.; Pavia, S.; Walker, R. Acoustic absorption of hemp-lime construction. Constr. Build. Mater. 2016, 122, 674-682. [CrossRef]

15. Diquélou, Y.; Gourlay, E.; Arnaud, L.; Kurek, B. Impact of hemp shiv on cement setting and hardening: Influence of the extracted components from the aggregates and study of the interfaces with the inorganic matrix. Cem. Concr. Compos. 2015, 55, 112-121. [CrossRef]

16. Diquélou, Y.; Gourlay, E.; Arnaud, L.; Kurek, B. Influence of binder characteristics on the setting and hardening of hemp lightweight concrete. Constr. Build. Mater. 2016, 112, 506-517. [CrossRef]

17. Balčiūnas, G.; Pundienè, I.; Boris, R.; Kairytė, A.; Žvironaitė, J.; Gargasas, J. Long-term curing impact on properties, mineral composition and microstructure of hemp shive-cement composite. Constr. Build. Mater. 2018, 188, 326-336. [CrossRef]

18. Fernea, R.; Tămaş-Gavrea, D.R.; Manea, D.L.; Roşca, I.C.; Aciu, C.; Munteanu, C. Multicriterial Analysis of Several Acoustic Absorption Building Materials Based on Hemp. Procedia Eng. 2017, 181, 1005-1012. [CrossRef]

19. Fernea, R.; Florea, I.; Manea, D.L.; Păşcuţă, P.; Tămaş-Gavrea, D.R. X-ray diffraction study on new organicnatural building materials. Procedia Manuf. 2018, 22, 372-379. [CrossRef] 
20. Koksal, F.; Gencel, O.; Kaya, M. Combined effect of silica fume and expanded vermiculite on properties of lightweight mortars at ambient and elevated temperatures. Constr. Build. Mater. 2015, 88, 175-187. [CrossRef]

21. Silva, L.M.; Ribeiro, R.A.; Labrincha, J.A.; Ferreira, V.M. Cement \& Concrete Composites Role of lightweight fillers on the properties of a mixed-binder mortar. Cem. Concr. Compos. 2010, 32, 19-24.

22. Garc1, P.A.; Lanzo, M. Lightweight cement mortars: Advantages and inconveniences of expanded perlite and its influence on fresh and hardened state and durability. Constr. Build. Mater. 2008, 22, 1798-1806.

23. Dunn, V. Collapse of Burning Buildings, 2nd ed.; PennWell: Tulsa, OK, USA, 2010.

24. Hussain, A.; Calabria-holley, J.; Lawrence, M.; Ansell, M.P.; Jiang, Y.; Schorr, D.; Blanchet, P. Development of novel building composites based on hemp and multi- functional silica matrix. Compos. Part B 2019, 156, 266-273. [CrossRef]

25. Pantawee, S.; Sinsiri, T.; Jaturapitakkul, C.; Chindaprasirt, P. Utilization of hemp concrete using hemp shiv as coarse aggregate with aluminium sulfate $\left[\mathrm{Al}_{2}\left(\mathrm{SO}_{4}\right)_{3}\right]$ and hydrated lime $\left[\mathrm{Ca}(\mathrm{OH})_{2}\right]$ treatment. Constr. Build. Mater. 2017, 156, 435-442. [CrossRef]

26. Jia, X.; Ansell, M.P.; Hussain, A.; Lawrence, M.; Jiang, Y. Physical Characterisation of Hemp Shiv: Cell Wall Structure and Porosity. In Proceedings of the 2nd International Conference on Bio-Based Building Materials \& 1st Conference on ECOlogical valorisation of GRAnular and Flbrous Materials, Clermont-Ferrand, France, 21-23 June 2017.

27. Abraham, R.E.; Wong, C.S.; Puri, M. Enrichment of cellulosic waste hemp (Cannabis sativa) hurd into non-toxic microfibres. Materials 2016, 9, 562. [CrossRef]

28. Terpáková, E.; Kidalová, L.; Eštoková, A.; Čigášová, J.; Števulová, N. Chemical modification of hemp shives and their characterization. Procedia Eng. 2012, 42, 931-941. [CrossRef]

29. Stevulova, N.; Cigasova, J.; Estokova, A.; Terpakova, E.; Geffert, A.; Kacik, F.; Singovszka, E.; Holub, M. Properties characterization of chemically modified hemp hurds. Materials 2014, 7, 8131. [CrossRef] [PubMed]

30. Chabannes, M.; Garcia-Diaz, E.; Clerc, L.; Bénézet, J.C. Effect of curing conditions and Ca(OH)2-treated aggregates on mechanical properties of rice husk and hemp concretes using a lime-based binder. Constr. Build. Mater. 2016, 102, 821-833. [CrossRef]

31. Delannoy, G.; Marceau, S.; Glé, P.; Gourlay, E.; Guéguen-Minerbe, M.; Diafi, D.; Nour, I.; Amziane, S.; Farcas, F. Influence of binder on the multiscale properties of hemp concretes. Eur. J. Environ. Civ. Eng. 2019, 23, 609-625. [CrossRef]

32. Brzyski, P.; Barnat-Hunek, D.; Suchorab, Z.; Lagód, G. Composite materials based on hemp and flax for low-energy buildings. Materials 2017, 10, 510. [CrossRef]

33. Stevulova, N.; Estokova, A.; Cigasova, J.; Schwarzova, I.; Kacik, F.; Geffert, A. Thermal degradation of natural and treated hemp hurds under air and nitrogen atmosphere. J. Therm. Anal. Calorim. 2017, 128, 1649-1660. [CrossRef]

34. De Oliveira, A.G.; Jandorno, J.C.; da Rocha, E.B.D.; de Sousa, A.M.F.; da Silva, A.L.N. Evaluation of expanded perlite behavior in PS/Perlite composites. Appl. Clay Sci. 2019, 181, 105223. [CrossRef]

35. Wang, W.; Wang, A. Vermiculite Nanomaterials: Structure, Properties, and Potential Applications; Elsevier Inc.: Amsterdam, The Netherlands, 2019.

36. Jahanshahi, R.; Akhlaghinia, B. Expanded perlite: An inexpensive natural efficient heterogeneous catalyst for the green and highly accelerated solvent-free synthesis of 5-substituted-1H-tetrazoles using [bmim]N3 and nitriles. RSC Adv. 2015, 5, 104087-104094. [CrossRef]

37. Abidi, S.; Joliff, Y.; Favotto, C. Impact of perlite, vermiculite and cement on the Young modulus of a plaster composite material: Experimental, analytical and numerical approaches. Compos. Part B 2016, 92, 28-36. [CrossRef]

38. Guenanou, F.; Khelafi, H.; Aattache, A. Behavior of perlite-based mortars on physicochemical characteristics, mechanical and carbonation: Case of perlite of Hammam Boughrara. J. Build. Eng. 2019, 24, 100734. [CrossRef]

39. Tian, Y.; Tang, Y.; Li, S.; Lv, H.; Liu, P.; Jing, Q. Voigt-based swelling water model for super water absorbency of expanded perlite and sodium polyacrylate resin composite materials. e-Polymers 2019, 19, 365-368. [CrossRef]

40. Zhou, Y.; Gan, X.; Xue, H.; Han, S.; Hou, J.; Feng, K.; Wang, X. Photocatalytic Degradation of Rhodamine B by $\mathrm{Fe}_{2} \mathrm{O}_{3} / \mathrm{TiO}_{2}$ Coated Expanded Perlite. Res. Environ. Sci. 2017, 30, 1961-1969. 
41. Nyenhuis, J.; Drelich, J.W. Essential Micronutrient Biofortification of Sprouts Grown on Mineral Fortified Fiber Mats. Int. J. Biol. Biomol. Agric. Food Biotechnol. Eng. 2015, 9, 981-984.

42. Sutcu, M. Influence of expanded vermiculite on physical properties and thermal conductivity of clay bricks. Ceram. Int. 2015, 41, 2819-2827. [CrossRef]

43. Wen, R.; Huang, Z.; Huang, Y.; Zhang, X.; Min, X.; Fang, M.; Liu, Y.; Wu, X. Synthesis and characterization of lauric acid/expanded vermiculite as form-stabilized thermal energy storage materials. Energy Build. 2016, 116, 677-683. [CrossRef]

44. Celik, A.G.; Kilic, A.M.; Cakal, G.O. Expanded perlite aggregate characterization for use as a lightweight construction raw material. Physicochem. Probl. Miner. Process. 2013, 49, 689-700.

45. Roulia, M.; Chassapis, K.; Kapoutsis, J.A.; Kamitsos, E.I.; Savvidis, T. Influence of thermal treatment on the water release and the glassy structure of perlite. J. Mater. Sci. 2006, 41, 5870-5881. [CrossRef]

46. Nozahic, V. Vers une nouvelle démarche de conception des bétons de végétaux lignocellulosiques basée sur la compréhension et l'amélioration de l'interface liant/végétal: Application à des granulats de chenevotte et de tige de tournesol associés à un liant ponce/. Available online: https://tel.archives-ouvertes.fr/file/index/ docid/822142/filename/Nozahic-2012CLF22265.pdf (accessed on 10 February 2020).

47. Arizzi, A.; Cultrone, G. Negative Effects of the Use of White Portland Cement as Additive to Aerial Lime Mortars Set at Atmospheric Conditions. Available online: https://ialnet.unirioja.es/servlet/articulo?codigo= 4293986 (accessed on 10 February 2020).

48. Prasad, R.; Mahmoud, A.E.R.; Parashar, S.K.S. Enhancement of electromagnetic shielding and piezoelectric properties of White Portland cement by hydration time. Constr. Build. Mater. 2019, 204, 20-27. [CrossRef]

49. Hosseini, T.; Flores-Vivian, I.; Sobolev, K.; Kouklin, N. Concrete embedded dye-synthesized photovoltaic solar cell. Sci. Rep. 2013, 3, 2727. [CrossRef]

50. Subaşi, A.; Emirołlu, M. Effect of metakaolin substitution on physical, mechanical and hydration process of White Portland cement. Constr. Build. Mater. 2015, 95, 257-268. [CrossRef]

51. Sivakugan, N.; Gnanendran, C.T.; Tuladhar, R.; Civil, M.B.K. Engineering Materials; Cengage Learning: Boston, MA, USA, 2018.

52. Ghalibaf, M.; Doddapaneni, T.R.K.C.; Alén, R. Pyrolytic behavior of lignocellulosic-BASED polysaccharides. J. Therm. Anal. Calorim. 2019, 137, 121-131. [CrossRef]

53. SR EN 520+A1:2010. Plăci de gips-carton. Definiţii, specificaţii şi metode de încercări. Available online: http://magazin.asro.ro/ro/standard/178726 (accessed on 10 February 2020).

54. SR EN 196-1:2016. Methods of Testing Cement. Determination of Strength. Available online: https://allbeton.ru/ upload/iblock/113/bs_en_196_1_1995_methods_of_testing_cement_part_1_determination_of_strength.pdf (accessed on 10 February 2020).

55. SR EN 12667:2002. Thermal Performance of Building Materials and Products-Determination of Thermal Resistance by Means of Guarded Hot Plate and Heat Flow Meter Methods-Products of High and Medium Thermal Resistance. Available online: https://shop.bsigroup.com/ProductDetail/?pid=000000000030087852 (accessed on 10 February 2020).

56. SR EN ISO 10534-2:2002. Determination of Sound Absorption Coefficient and Impedance in Impedance Tubes. Part 2: Transfer-Function Method. Available online: https://www.iso.org/obp/ui/\#!iso:std:22851:en (accessed on 10 February 2020).

57. Tiuc, A.E.; Vermeşan, H.; Gabor, T.; Vasile, O. Improved Sound Absorption Properties of Polyurethane Foam Mixed with Textile Waste. Energy Procedia 2016, 85, 559-565. [CrossRef]

58. Nguyen, D.D.; Devlin, L.; Koshy, P.; Sorrell, C.C. Quantitative X-Ray Diffraction Analysis of Anhydrous and Hydrated Portland Cement-Part 1: Manual Methods. Adv. Mater. Res. 2015, 1087, 493-497. [CrossRef]

59. Gritsch, L.; Conoscenti, G.; La, V.; Nooeaid, P.; Boccaccini, A.R. Materials Science \& Engineering C Polylactide-based materials science strategies to improve tissue-material interface without the use of growth factors or other biological molecules. Mater. Sci. Eng. C 2019, 94, 1083-1101.

60. Ananda, K. Eco-Friendly Nano-Hybrid. Materials for Advanced Engineering Applications; Apple Academic Press: Palm Bay, FL, USA, 2016.

61. Cerro-prada, E. Cement Microstructure: Fostering Cement Fostering Photocatalysis Photocatalysis. Available online: https://www.intechopen.com/books/cement-based-materials/cement-microstructurefostering-photocatalysis (accessed on 10 February 2020). 
62. Hilal, A.A. Microstructure of Concrete, High Performance Concrete Technology and Applications; Intechopen: London, UK, 2016. [CrossRef]

63. Gadde, H.K. Effect of Hydration and Confinement on Micro- Structure of Calcium-Silicate-Hydrate Gels. Available online: https://pdfs.semanticscholar.org/bb10/7d64b7936133f72f613241290d84ad9b9c6b.pdf (accessed on 10 February 2020).

64. Couto, C.; Darc, J.; Godoy, G.C. Microstructural and Topographic Characterization of Concrete Protected by Acrylic Paint. Mater. Res. 2013, 16, 817-823.

65. Jun, Y.; Kim, J.H.; Kim, T. Hydration of calcium sulfoaluminate-based binder incorporating red mud and silica fume. Appl. Sci. 2019, 9, 2270. [CrossRef]

66. Aïtcin, P.C. Portland Cement; Elsevier Ltd.: Amsterdam, The Netherlands, 2015.

67. Ogirigbo, O. Influence of Slag Composition and Temperature on the Hydration and Performance of Slag Blends in Chloride Environments Influence of Slag Composition and Temperature on the Hydration and Performance of Slag Blends in Chloride Environments Okiemute Roland O. Available online: https://www.researchgate.net/publication/305641458_Influence_of_Slag_Composition_and_Temperat. ure_on_the_Hydration_and_Performance_of_Slag_Blends_in_Chloride_Environments (accessed on 10 February 2020).

68. Kolvari, E.; Koukabi, N.; Hosseini, M.M. Perlite: A cheap natural support for immobilization of sulfonic acid as a heterogeneous solid acid catalyst for the heterocyclic multicomponent reaction. J. Mol. Catal. A Chem. 2015, 397, 68-75. [CrossRef]

69. Xu, B.; Ma, H.; Lu, Z.; Li, Z. Paraffin/expanded vermiculite composite phase change material as aggregate for developing lightweight thermal energy storage cement-based composites. Appl. Energy 2015, 160, 358-367. [CrossRef]

70. Stevulova, N.; Kidalova, L.; Cigasova, J.; Junak, J.; Sicakova, A.; Terpakova, E. Lightweight composites containing hemp hurds. Procedia Eng. 2013, 65, 69-74. [CrossRef]

71. Arnaud, L.; Gourlay, E. Experimental study of parameters influencing mechanical properties of hemp concretes. Constr. Build. Mater. 2012, 28, 50-56. [CrossRef]

72. Balčiunas, G.; Vejelis, S.; Vaitkus, S.; Kairyte, A. Physical properties and structure of composite made by using hemp hurds and different binding materials. Procedia Eng. 2013, 57, 159-166. [CrossRef]

73. Salama, A.E.; Ghanem, G.M.; Abd-Elnaby, S.F.; El-Hefnawy, A.A.; Abd-Elghaffar, M. Behavior of thermally protected RC beams strengthened with CFRP under dual effect of elevated temperature and loading. HBRC J. 2012, 8, 26-35. [CrossRef]

74. Koizumi, T.; Tsuijuchi, N.; Adachi, A. The Development of Sound Absorbing Materials Using Natural Bamboo Fibers and Their Acoustic Properties. Available online: https://www.researchgate.net/publication/ 285676084_The_development_of_sound_absorbing_materials_using_natural_bamboo_fibers (accessed on 10 February 2020).

75. Tiuc, A.E.; Nemeş, O.; Vermeşan, H.; Toma, A.C. New sound absorbent composite materials based on sawdust and polyurethane foam. Compos. Part B Eng. 2019, 165, 120-130. [CrossRef]

76. Ghofrani, M.; Ashori, A.; Mehrabi, R. Mechanical and acoustical properties of particleboards made with date palm branches and vermiculite. Polym. Test. 2017, 60, 153-159. [CrossRef]

77. Glé, P.; Gourdon, E.; Arnaud, L. Acoustical properties of materials made of vegetable particles with several scales of porosity. Appl. Acoust. 2011, 72, 249-259. [CrossRef]

(C) 2020 by the authors. Licensee MDPI, Basel, Switzerland. This article is an open access article distributed under the terms and conditions of the Creative Commons Attribution (CC BY) license (http://creativecommons.org/licenses/by/4.0/). 